
H 55

\title{
Hill
}

A Linguatulid From The Alligator. 



\section{A LINGUATULID FROM THE ALLIGATOR}

BY

HOW ARD RICE HILL

A. B. Carroll College, 1913

THESIS

Submitted in Partial Fulfillment of the Requirements for the Degree of

MASTER OF SCIENCE

IN ZOOLOGY

IN

THE GRADUATE SCHOOL

OF THE

UNIVERSITY OF ILLINOIS

1916 



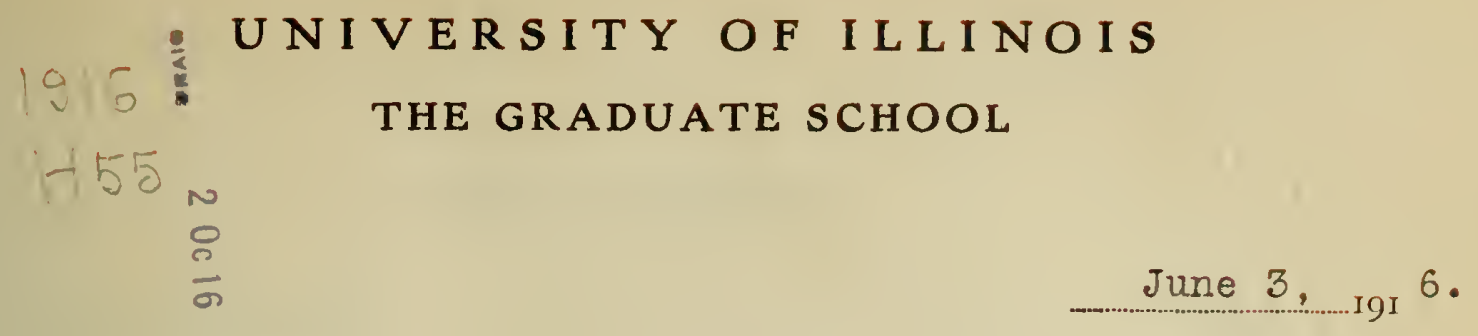

I HEREBY RECOMMEND THAT THE THESIS PREPARED UNDER MY SUPERVISION BY HOWADD RICE HILI

ENTITLED A IINGUATULID FEOK THE AILIGAMOS

BE ACCEPTED AS FULFILLING THIS PART OF THE REQUIREMENTS FOR THE DEGREE OF. MISTER OF SCIENCE

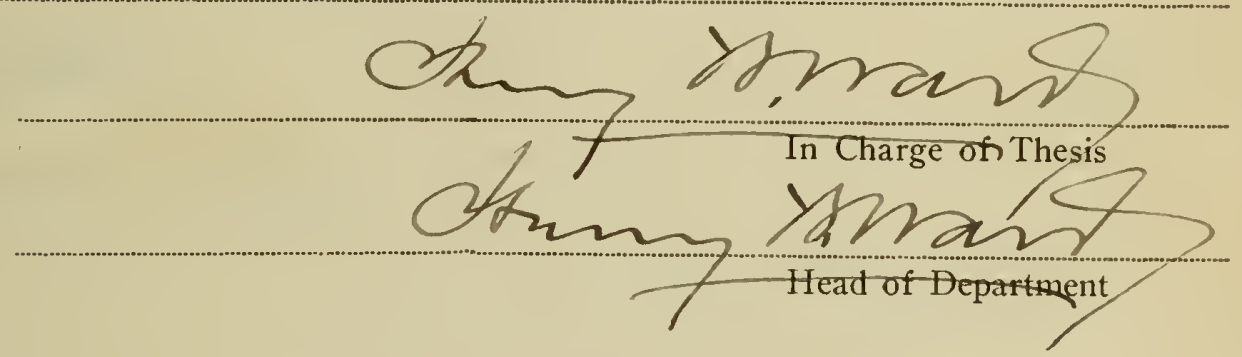

Recommendation concurred in :*

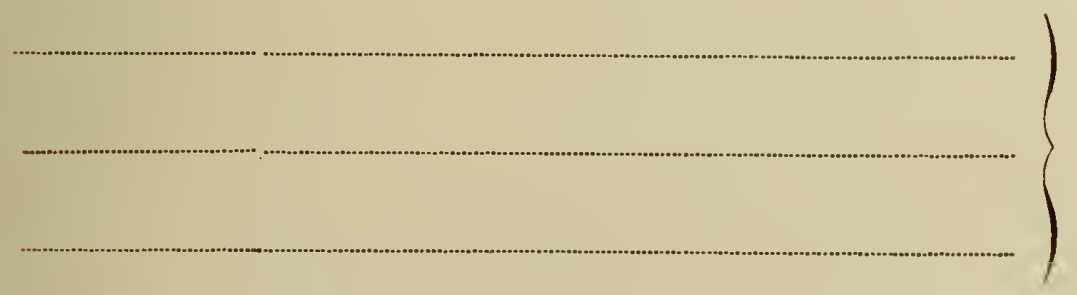

\section{Committee}

on

Final Examination*

*Required for doctor's degree but not for master's. 

TABLE OT CONTENTS

I. Irtroduction

Page 1

II. Historice.1

III. External Anatomy of the Free Iorva 6

IV. Internal. Anatomy of the Free Larva 19

V. The Encysted Larva 30

vI. Iife History

31

VII.Systematic Position and Classification

VIII. Bibliography

IX. ixplanation of Plates 



\section{INERODUCEI JH}

There is probably no grour of internal carasites that has been so neglected by zoological investigutors $:$ s the Iingu:tulidee. A number of different species of this aberrant family of the Arachnida have been reported from American animals but as yet very little detailed study has been made in this country either with regerd to the life history or the morphology of the group. This situstion has been due, no doubt, to a lacir of available material, for these parasites are not freouently encountered in animal dissections. When present, they usually occur in limited numbers, seldom more than five or six individuals being found in a single host and more often a le:s number. on the other hend, in tropic 1 countries and in Europe, the Iinguatuliaae are far more numerous and are represented by twenty or more different species. There, certin species are know to infect even man. Consequently they have received more attention from the coreign zoologist and medicl practitioner, the former has studied them from a morphological point of view while the latter has endeavored to show their pathoiogical imoortance.

The injurious effects of the parasite have veen frequently observed in some of the common domestic animals. On the otrer hand, it has long been a matter of doubt as to whether or not they seriously impair the henlth of the human host. But it has been shown recently by iacfie, Johnston, Chalmers and others that the lerval forms undoubtedly cause a disessed condition which sometimes results in the death of the rost. liacie and Johnston give the record of five cases of larval infection in 


\section{Digitized by the Internet Archive in 2013}


native Africans who were patients in the native hospitals. In each case, the natient died after a brief illness without having shown any symptoms of a specific disease. The post-mortem examinations disclosed the presence of larvae in the liver and other orgns, and an accompanying diseased condition in the region of the organs affected. The conclusion wis reached that the parasites were, in each case, partially if not wholly responsible for the death of the patient. Chalmers records the cose of a negro from Sierra Leone where the presence of larvae set up inflammetion in the lungs and the peritoneum. In this cuse the varasitic infection was tre immediate cause of death.

Dorocephaliasis, as the disease is mown, is no longer regarded as a Hirmless infection, and its pathological importance is now fully recognized. Mherefore a thorough knowledge of tre structure and development of the Iinguadulidae is of vilue from the medical standpoint lone. liuch work is jet to be done with the morphology of the group. lany species heve been very incompletely described. In some inst nces tre description of the internal anatomy his been omitted altogether. ¿lso, the problem of development has been only touched upon by a few workers. leuckart stiles, and one or two otrers reve done some amirable work with tre more common species, but practically nothing is known of the life history of the rarer forms.

In the fall of 1915 , the author bepin the study of a linguatulia perasitic in the American alligator, Alligator mississippiensis. The work was undertaken at the suggestion of Erofessor Henry 3. Ward and carried on under his airection. To him the author is greatly indebted for the naterial which was 

used as the basis of the investigation and for advice and criticism during the progress of the study. The object of the investigation has been to determine if possible the species of the narasite and to desuribe its complete morphology. 



\section{HISTORICAI}

The pentastomes or linguatulids form a group of very degenerate Arachnida and are now regarded as being closely related to the acarids. Por a long time their phylogenetic position was a matter of much speculation. Wrisberg in 1765 , first observed these parasites and thought they belonged to the Hirudinei. Some time later, Brasador 1774 found them infesting dogs in Trance and believed them true worms. In 1787. Chabert observed them in the horse and gave them the name "Tenia lanceole" and "Ver rhinaire" thus placing them in the Cestoda. The first genus, Iinguatula, was esteblished by Frohlich 1789, who described the species from the hare and named it Iinguatula serrata and this proved to be the same form previously discovered by Chabert and the others. The genus Porocephelus was created by Eumboldt 1811 who had obtained a different species from the American snake, Crotclis sp. He first regarded the parasite as an acanthocephalid, later as a distome and finally put it in a separate genus Porocephalus. Both genera were included by Rudolphi (1819) in a single new genus Pentastomum which has been used extensively. The genera Iinguatula and Porocephalus, according to rules of zoological nomenclature can not be disregarded and at the present time are recognized as correct rather than Rudolphi's genus.

There has been a considerable difference of opinion as to the affinities possessed by the Iinguatulidae. Rudolphi thought they belongod to the mrematoda while irordmann 1832 believd them near the Nematoda. Their exact position was 

not thoroughly established however, until van Beneden in 1848 showed their true crustacean character and placed trem near the Lemaeidae. It was left to Schubart (1853) and Ieuckart (1860) to point out their close relationship with the Acarina and following them, Railliet has confirmed their conclusions. On the other hand. Ihle (1889) differs from the views taken by Leuckart and the others and places them in a subphylum of the Tracheata. Wore recently, Sambon (1910) agrees with Leuckart and gives some additional reasons for placing them along with the Acarina. He believes their vermiform appearance and structural modificetions have been brought about by an endoparasitic mode of life. The blood sucking habit and the fact that they foster the sporogonic cycle of haemogregarines of the reptilian hosts, at once suggests relationship with the ectoparasitic Ixodidae. 



\section{III.EXTERNAI ANATOMY OF THE FREE IA?VA}

The material which was placed at my disposal

consisted of a coliection of twenty nine linguatulids from the lungs of Alligator missigsippiensis. The specimens were obtained JulJ 24, 1915, near Mandeville, La. and were in good state of preservation, the preserving agent being formol. Mwenty two of the specimens were in the free larval stage of the parasite while seven wore enclosed within cysts.

The free larvae were more or less bent and twisted, a fact which might indicate that they haa escaped from their cysts only a short time before they were taken from their hosts. Eight of the twenty two were injured to some extent, one or both ends having been broken away. The remainder, howover, were entire and offered a good opportunity for the study of the external anatomy. The specinens were first studied in a liquid medium ( $\Lambda$ lcohol $75 \%$ ) under the dissecting microscope. All the specimens in the material unfortunately proved to be males. Otharwise additional comparisons might be made betreen the two sexes with regard to structure and size. The nales, however, show the characteristics of the species at hand.

$$
\text { Description. The larva is of a dirty white color, }
$$
slightly tinged with yellow. The form of the body is cylindrical, elongate and worm like, tapering toward either end (Fig. I). The ends are rounded and tho posterior end is slightly wider than the anterior tip. The specimens vary considerably in size as can be seen frot the following table. 

Table I.

Specimen Annuli Iength wiath at Wiath at Width at loth annulus 30th ann. 50th ain.

$\begin{array}{llllll}\text { A I } & 64 & 4.08 \mathrm{~mm} . & 0.522 \mathrm{rm} . & 0.581 \mathrm{~mm} \cdot & 0.290 \mathrm{~mm} \text {. } \\ \text { A II } & 62 & 5.4 & 0.437 & 0.48 & 0.304 \\ \text { A IV } & 60 & 4.35 & 0.342 & 0.43 & 0.247 \\ \text { A VII } & 64 & 5.2 & 0.513 & 0.53 & 0.418 \\ \text { A VIII } & 66 & 4.2 & 0.561 & 0.57 & 0.323 \\ \text { A IX } & 60 & 7 . & 0.561 & 0.589 & 0.399 \\ \text { F I } & 62 & 4.1 & 0.532 & 0.54 & 0.38 \\ \text { F II } & 65 & 4.18 & 0.38 & 0.418 & 0.247\end{array}$

The average length is $4.8 \mathrm{~mm}$. and the average width at the center of the body is $0.525 \mathrm{~mm}$. The body is divided into quite distinct regions. The greater part is taken up by the posterior abdominal region which is covered with a series of rings or annulations nearly uniform in width. In different individuals the number of the annuli varies from 60-66, but the specimens of greatest length do not necessarily have the largest number of rings. The short anterior head region or cephalothorax is comoletely devoid of annuli but a number of folds or rugae are present which give the lateral edges a rough outline (Fig. $2 r$ ).

Cephalothorax. This resion is about equal in length to the breadth of the body at the anterior margin of the abdomen. Prom this margin, the had rapidly narrows in width toward the anterior tip which is the narrowest part of the body. Weasurements of the cephalothorax. 

iale II.

Specimen Length Anterior width Posterior width
A II
$0.304 \mathrm{~mm}$.
$0.209 \mathrm{~mm}$.
$0.266 \mathrm{~mm}$.
A III
0.323
0.2
0.342
A IV
0.204
0.19
0.266
A VII
0.266
0.19
0.361
A VIII
0.247
0.171
0.361

A lateral view shows tine cephalothorax to be flattened dorsally and flexed ventrally at an angle of 45 degrees. The bending begins in the anterior part of the abdomen, in the region of the fourth anterior annulus.

In order to bring out the more minute structures of the head and abdomen, a number of toto mounts were made of both stained and unstained specimens. Borax carnine, altho penetrating more slomly than some of the other stains, was found to give the best results.

Upon closer exmination of the cephalothorax with higher magnification, a number of aditional structures are to be observed. On the midventral line, about half way between the anterior tip and the first annulus, is situated the mouth opening, bordered with a chitinous band. On either side of the mouth tinere are two hools, Iying about nidway between the lateral edge of the body and the midvontral line. The hooks are set obliquely amay from the mouth at an angle of 25 degrees. They are two pronged and consist of a straight upper projection and a lower basal portion in which the outer extremity is 

strongly recurved. On the lateral edges there are several prominences; they are equidistant from the median line, arranged in pairs, three on either side. These are the papillae or organs of special sense.

Wouth. The mouth is recognized by an oval or pear shaped ring of chitin, lying in the midventral line, $0.095 \mathrm{~mm}$. anterior to the first arnulus and $0.076 \mathrm{~mm}$. from the anterior end of the body. It is $0.1 \mathrm{~mm}$. Iong and 0.062 mrn. wide at the center and gradually narrows to a width of $0.025 \mathrm{~mm}$ at the anterior end. The lower apex narrows more rapidly until it measures $0.016 \mathrm{~mm}$. in width at the lower margin. The chitinous border is thichest along the center of the mouth where it is 7 micta in thickness, and thinnest along the posterior margin where it is 2 micra wide. In the anterior region of the mouth, the oral papila, a triangular shaped projection extends out from the border. From the ventral side it is hardy discernable, but viewed laterally and in cross sections it is very evident. Together with the other papillae of the cephalothorax, its function and structure will be discussed in another place. A sort of flap is attached to the lower border and extends inward on either side to a width of $0.01 \mathrm{~mm}$. While along the posterior apex of the mouth its width is $0.014 \mathrm{~mm}$. This flap does not reach as far as the center of the mouth and is only present along its lower border. In many of the specimens the flap could not be detected, but in others it is readily apparent. Attached to the flap and the border are the pharyngeal muscles leading 

down into the pharynx. They extend entirely around the inner wall of the mouth and thicken at the anterior apex where there is a short interval measuring $0.019 \mathrm{~mm}$. cansed by the oreaking of tre chitinous border.

Hooks. The double pointed hooks which are used by the parasites for attaching themselves to the tissues of the host, lie on either side of the mouth. They are golden yellow in color and are composed of a hard chitinous substance. The anterior,pair are slightly nearer the midcentral line of the body and are not quite as large as the posterior pair. Where the hooks enter the body, the cuticle is folded back and a ridge is formed around esch external base, with a slight depression between the ridge and the hook. These depressions are known as the hook pits and are common to most species of Linguatulidae. In this case they are comparatively narrow and can only be detected in mounted specimens.

In order to further describe the position of the hooks, it will be necessary here to go sumewhat into detail with regard to their structire. Each hook is composed of tinree distinct parts, (I) an upper accessory spike with a long narrow basal plate, (2) a lower sharply recurved hook with a broad base, (3) a very thin chitinous sheath which covers the basal portion of the upper projection and a part of the base of the lower hook. The total length of the accessory spike is $0.29 \mathrm{~mm}$. and about one third of this length is the only portion visible outside of the body. The width of the long basal plate vithin the body is $0.018 \mathrm{rm}$. Then the exterior is reached, the spike begins to narrow and 

taoes off to a sharp point. The basal plate on the other hand is quite constant in width until the inner end is reached where it suddenly rounds off. The projecting part lies closely approximate to the top and anterior side of the lover hook. The lower hook is bent a $t$ a sharper angle than the upper thereby causing $0.041 \mathrm{~mm}$. of the spike to stand out free. The shortest distance from the point to the surface of the lower hook is $0.021 \mathrm{~mm}$. At the place where the internal prolongation begins there is a slight incurvature of the upper edge and a corresponding widening at the lower edge approximate to the lower hook. The anterior side of the lower hook is accordingly indented to some extent. A dark shaded portion in the center of the main spike shows up prominently. This indicstes, perhaps, that the spize is hollow and that there is amedian groove, though no outlet to the groove can be seen. Examination of a cross section of the hook at this point shows the hollow character of the accessory spike very plainly. With respect to the function of the accessory spike, it is probable that it serves a double purpose. In the first place it acts as a catch or anchor for the main hook. Piercing the tissue of the host at a different angle, it tends tp prevant the dislodgement of tine lower hook until it is finally broken off at the end of the larval period. Purthermore, it is a source of irritation in the tissue, causing blood or mucous to be secreted. This the parasite immediately uses as food by sucking it dow its large mouth opening, The portion of the spike within the body 

together with the overlying sheath act as a base of support for the entire hook. To them most of the hook muscles are attached, some connecting with the lower hooks, others with the body.

The lower hook is much broader than the accessory spike, but not as long. It is otherwise different in that it is more strongly curved and has a frontal supporting plate on the lower side. Its length taken thru the center is $0.06 \mathrm{~mm}$. The length of the inner poction is $0.025 \mathrm{~mm}$. at the center and $0.039 \mathrm{~mm}$. in the region of the supporting plate. Soon aiter locving the body the hook begins to narrow and then bend inverily until $005 \mathrm{~mm}$. of its outer length lies parallel with the supporting plate of the lower side. It terminates in a sharp point which is closely approximate to the body surface. This position of the lower hook allows the mouth to come into close contact with the tissue of the host. The frontal supporting plate at the lower edge is $0.014 \mathrm{~mm}$. wide and is somevinat fan shaped. Near the end it has a triangular projection on the inner side which extends out into the adjacent muscle fibers. A muscular band fills up the center of the hook for a distance of $0.035 \mathrm{~mm}$. and ends abruptly near the center of the hook just without the body. The muscles within the band and the other hook muscles will be dealt with later under the muscular system. Here, as in the upper hook, there is a darker central region in the portion of the hook within the body, suggesting the presence of a hollow chamber within. 

An extremely thin chitinous sheath fits closely over the basal plate of the accessory spike and a small portion of the lower hook. It no doubt serves as a protection for the upper hook muscles, and to bind tightly together the upper and lowar hooks. The width of the sheath is $0.035 \mathrm{~mm}$. and the length $0.19 \mathrm{~mm}$. extending inwardly a little beyond the end of the basal plate. It is quadrangular in shape and fairly uniform in width. The outer termination lies within the body and is more or less square across, while the inner termination is rounded. The outline is similar to that of a banana. There are muscle connections with the lower hook both from the outer and inner surfaces of the sheath.

For a short distance from the pointed ends the hooks are perfectly round, but as they approach the point where they start to bend there is a gradual broadening in the vertical plane. This condition is more noticeable in the lower hook. here the center of the hook is nearly twice as broad as thick. The basal plate of the upper spike and the sheath form the main supporting base for the whole hook. They are bent at the midale, thus throwing the hook forward, and giving them the outline of an arc. The supporting plates of the posterior pair of hooks have a broader curve than those of the upper pair. This tends to set the lower hoirs farther out from the median line. The distance between the frontal plates of the anterior hooks is $0.2 \mathrm{~mm}$., and in the posterior pair $0.232 \mathrm{~mm}$. The supporting plates of the posterior hooks lie just without the lower boraer of the mouth, while the position of the mouth with ragard to the plates of the 

anterior pair is directly ventrad. The lower margin of the mouth is on the same plane horizontally as the posterior end of the frontal plates of the posterior hooks, while the upper edge of the mouth is on the same plane with the plates of the anterior hooks. The distance between the anterior and posterior hooks is $0.1 \mathrm{~mm}$. measured from the anterior surface. The supporting plates in the anterior hooks nearly meet in the median line while those of the posterior pair are $0.035 \mathrm{~mm}$. distant where they come nesrest together. The posterior margins of the supporting plates in the posterior hooks are $0.036 \mathrm{~mm}$. anterior to the first annulus.

Papillae. There are six prominent papillae along the lateral margin of the ventral surface of the cephalothorax. They lie just without the line of the hooks, three on each side of the head. They are arranged in three pairs, the papillae in each pair being exactly opposite. The first pair or primary papillae are slightly larger than the others and jut out from the extreme anterior border of the ventral face, one at each corner. The distarce from the base of each to the midale is $0.034 \mathrm{~mm}$. and to the edge of the anterior hook pits $0.035 \mathrm{~mm}$. The papillae are all of the same shape, a cone with a rounded tip. The base id the widest portion and there is a gradual decrease in width to the tip which rounds off abruptly. The primary papillae are $0.02 \mathrm{~mm}$. in length, $0.028 \mathrm{~mm}$ in width at the base and $0.018 \mathrm{~mm}$. in width at the tip. The first pair of secondary papillae are 0.012 $\mathrm{mm}$. further from the midventral line and lie $0.015 \mathrm{~mm}$. 

anterior to the first pair of hooks. They are $0.027 \mathrm{~mm}$. from the base of the primary papillae. The third pair lie on a even line with the posterior hooks and $0.03 \mathrm{mrn}$. posterior to the second pair. They are $0.061 \mathrm{~mm}$ from the midcentral line and in size agree with the secondary papillae. The oral papilla which arises from the mouth opening can only be detected by viewing the cephalothorax from the side. It nearly fills the space of the mouth aperture and is longer and more stretched out at the base than the other papillae. It is triangular in shape, the apex pointing anteriorly and the posterior margin being the broad end. The distance to the tip is $0.028 \mathrm{~mm}$. and the base measures $0.02 \mathrm{~mm}$. wide in the horizontal plane and $0.045 \mathrm{~m}$. wide in its broadest part. At the lower border is the transverse opening which leads directly into the pharynx. ugae. The cuticle in the posterior part of the cephalothorax is ridged transversely, giving the lateral margins a rough outline. The rugae or folds are narrow and uneven. They begin just arterior to the first annulus and are present as far forward as the posterior hooks where the cuticle presents an even surface. In some specimens it is difficult to determine where the annuli begin because of the similar notched appearance of the latersl edge in the region of the first annuli and the posterior part of the cephalothorax. Abdomen. The abdomen occupies the greater part of the length of the body. It is somewhat flattened along the ventral surface and rounded at the posterior end. It is considerably wider than the cephalothorax except at the 

extreme end. The average length is $4 \mathrm{~mm}$. and the average width is $0.5 \mathrm{~mm}$. Soon after leaving the cenhalothorax, it begins to widen and reaches its maximum width in the region between the sixteenth and twentyfirst annuli. Srom that region, it gradually decreases in size posteriorly. The posterior third is bent ventrally at an angle of about 45 degrees. Along its whole length, it is marked by a series of rings or anulations. These are fairly uniform thruout except in the center of the body where they widen perceptibly. The average length taken with respect to the long axis of the body is $0.3 \mathrm{~mm}$. and the width conforms to that of the body. The terminal annulus is cone shaped and slightly longer than the preceding ones. It bears the subterminal anus on the midline of the ventral side, $0.03 \mathrm{~mm}$. from the postexior tip. Each annulus is divided into two portions, the anterior larger portion which slopes gently toward the front margin and a posterior raised portion. The posterior part slopes abruptly towards the posterior edge, and bears at its interin edge the rows of spines which point posteriorly.

\section{Spines. A border of sharp pointed tooth like}

projections extends entirely around the body, just posterior to the center of each annulus. They lie along the ridge that separates the annulus into two parts, the sharp ends pointing posteriorly. The average distance between the spines is 5 micra. In some places they are huddled close together while in others they are stretched apart. Bach spine is the shape of a pen point with its base extending thru the cuticle 

into the epitheliar beneath. The average length is 9 micra and the width thru the base is two micra. The cuticle is attached to the sides until the spine berins to slope toward the point. Between the spines, where they are not stretched apart, the cuticle sags inwardy. This indicates that the spines are able to move from side to side. However, there are no muscles connecting the base with either the epithelium or the cuticle.

Stigmeta. A row of sinall round pores or stigmata extonas completely around the body in the anterior region of each annulus. Their position is just anterior to the center of the annulus. Their arrangement is sometimes irregular for they do not always form a straight line. Altho no definite border surrounds the pores, they give the appearance of being slightly raised from the surface of the cuticle. In diameter they measure 1.5 micra and the distance between them is 21 micra. In the cephalothorax they are lacking altogether.

\section{Genital Opening. The male genital opening lies} on the midventral surface of the center of the first annulus. It is oval in shape and surrounded by a narrow raised border. Around the outer portion of the border is a lov area in the cuticle. The length of the opening in an antero-posterior direction is 20 micra and the width is 12 micra while the width of the surrounding border is 3 micra.

\section{Alimentary Tract. The long yellowish brown} intestine, extending thru the entire length of the body 

is the first prominent internal structure to be noted. The anterior portion is somevhat extended, while in the posterior region of the body, its width is more or less uniform. Soon after leaving the cephalothorax, it begins a lateral bending, which is more pronounced in the middle region of the body. As the posterior end is approached, there is a gradual straightening. Two large masses of cells are present on either side along most of its length. 



\section{IIMERITAI ANATOMY OF MHE FREE LARVA.}

Technique. A number of series of cross sections were made in order to study the arrangernent of the internal structures, and to check up with the observations made of the toto mounts. In addition several specimens were sectioned longitudinally to show to better advantage the relationshios of the muscles of the body wall and other structures. The stain used was Delafield's haematoxylin which was found sctisfactory in every way and especially good for bringing out the chroratic material of the reproductive organs and the cell nuclei.

\section{Structure of the Body ill. A transparent non-} cellular membrane or cuticle covers the entire body surface, and extends into the mouth aperture, the anal opening and the hook pits. It is composed of hard chitinous material that is resistent and impermeable to liquids. In staining specimens, it is necessary to leave them in the staining fluid a longer time than is customary with most tissues. Extra time must also be alloved for infiltration in the paraffin bath because of the poor penetration thru the cuticle. In cutting sections, unless the knife is exceedingly sharp, the cuticle is resistent to the edge and tears thru the section. In thickness, the cuticle is uniform over all parts of the body except along the hook pits, wh ere there is a slight decrease in thiciness. On the outer edge is a very narrow border that stains darker than the rest. It is 1 micron thick while the main cuticle is 11 micra in thickness. Seen in cross 

section, the cuticle is quite transparent and devoid of cells except where the stigmata break thru from the epithelial lining beneath.

A single scattered row of cells is present directly beneath the cuticle. They are uniform in size and measure $0.04 \mathrm{~mm}$. in diameter. In the anterior region of each annulus, just below the stigmata, numbers of the se cells are often masses together with their rounded ends pointed away toward a common center. Their function is probably of a secretory nature and connected with the work of the stigmata as a short narrow canal leads frorn these cells to the stigmata.

There are three types of muscles in the body wall, (1) transverse, (2) longitudinal and (3) oblique. The first set of muscles below the subcuticular epithelium is a thin layer of transverse muscle fibers, which is present over the entire body except in the head region. The trunsverse fibers are usually one layer thick but are occasionally arranged in a double layer. A cross section thru the body wall shows the fibers to be hollow, and circular in cross section. The layer is uniform in thickness around the circumference of the body, a condition unlike that which spencer found in $P$. tertiusculum where the transverse layer thinned out along the dorso-lateral region of the body wall.

The longitudinal lajer which lies directly below the trangverse layer is, thicker than the former and arranged in a different manner, Two layers of fibers are continuous over the surface, except ventrally in the region of the hooks. 

Along the circumference there are six regions where the fibers tend to band together and thicken the layer into more than two rows. The two lateral bands contain the greatest number of fibers and form a sort of lateral line. Spencer attributes this lateral line to the thinning out of the transverse fibers at this point, but in this c ase the transverse fibers are present in normel numbers. The longitudinal fiber is hollow like the transverse type but the nucleus is larger and stains a darker color than the former.

The oblique muscles are attached to the lateral body wall $0.031 \mathrm{~mm}$. from the middorsal line and extend obliqueIy across the body cavity to a point near the midventral line of the body wall. The fibers are arranged in parallel rows on either side of the body. They are placed a little apart from each other and do not form a continuous layer. The ends are often splitinto fibrils which become embedded in the network of parietal cells along the edge of the body wall. Toward the posterior end, cauad of tine hook glands, the oblique muscles divide the body cavity into three parts, the large central cavity and the two lateral pockets. In the hook gland region, the fibers do not stand out prominently, but are wedged in botween the glands and the body wall. In some instances where the hook glands are smaller and not diffuse, the oblique fibers stand out free. In the ceplalic region the oblique fibers are lacking. 

The Hook inscles.

The muscles of the hook take up

the greater part of the space in the head region. They are arranged in four fan shaped masses, two connected with the hook itself, while the other two sets are attached to the basal supporting plate. The flexor of the hook is attached to the posterior side of the frontal plate and spreads out as it extends toward the lower portion of the basal supporting plate where it ends. Its function is to bend the hook so the point of the main hook moves toward the surface of the body, The extensor muscle connects with the hook at a point near the upper angle of the main hook not far distant from the end of the sheath. It extends back to the posterior portion of the sheath and basal suoporting plate where a portion is attached and the remainder passes on into the body wall. The extensor is the largest of the hook muscles and its function is to throw the hooks forwara. The external protractor connects the upper portion of the sheath with the body wall. It spreads out towerds the anterior modian line and its action causes the hook to be thrown forward and down. The ventral retractor, the smallest of the four muscles, arises at the lower end of the frontal plate near the bottom of the hook pit. This muscle extends posteriorly and its function is to aid in retracting the hook. A cross section thru the hooks shows aditional muscle fibers, indefinitely arranged, attached to the sides of tine hook pit. Their purpose is to pull back the walls of the hook pit as the hook is extended. 

Organs of Special Sense. The papillae of the

cephalo-thoracic region are recognized as organs of special sense. This is undoubtedly true with respect to the primary papillae where there is a nerve which extends to the tip and a median narrow canal leading to the surface. A lateral view shows the division of the cuticle at the end of the papilla and the tube passing up between is the upper prolongation of of the hook gland auct. In the other lateral papillae neither duct.or nerve is present and the cuticle extends evenly over the surface of the papiliae. The primary papillae are the "Tastpapillen" of Leuckart who considered them organs of taste. It is more probable however, that they serve as touch sense organs. Spencer is of the opinion that they are used for deeling and smelling. The inar lining of all the papilláe is similar. A single row of epithelial cells is present and in the primary papillae they extend down either side of the hook giand tube. In the oral papilla, there are in adition, longitudinal muscle fibers below the cuticle. Glandular Structures. The hook glands are the largest structures of the body cavity. They are arranged in a single pair, one gland on either side of the alimentary canal. Beginning slightly below the atrium genitale, they extend to the fifteenth annulus from the posterior end of the body. In shape they are long and cylindrical and taper somewhat posteriorly. They are connected to the alimentary canal by mesenteries, one on either side of the canal. Each mesentery consists of a main strand with branching fibers at 

the ends which connect with the gland wall and the wall of the alimentary canal. A network of thin fibers crosses the larger strands. Exactly in the center of the main strand is the hook gland duct. Whe cells composing the hoois gland are the largest cells of the body. Whey are triangular in shape with the corners rounded, the narrow ends pointing toward the hook gland. In each cell a large, deeply staining nucleus is present and a delicate membrune surrounds the cell. The cells vary in size in the same specimen, the average length being $0.09 \mathrm{~mm}$., but some measure as much as $0.17-18 \mathrm{~mm}$. they are arrange in closely packed masses and not in a definite layer. In some specimens the hook glands are much more diffuse than in others. Here, they take uo nearly the whole body cavity, and crowd the oblique muscles to the body wall. In younger specimens their size is limited and they are seldom over three or four times as large as the intestine. Various theories have been put forth as to their probable function. spencer suggested that theysecrete a substance to prevent the coagulation of blood, which is a part of the food of the parasite, while leuckart believed their secretion irritates the tissue of the host, thereby causing more mucous and other nutrient material to be given off.

Head Gland. In the center of the head region there is a mass of cells similar in character to the hook gland cells, but smaller in size. These comprise what is known as the head gland. In cross section the gland appears slightly dorsal to the basal supports of the hooks as a more or less scattered group of cells without a limiting membrane. 
Parietal Cells. The parietal cells appear along the lateral edge of the body cavity in the abdomen and completely encircle the body cavity in the cephalothorax. In the abdomen they lie approximate to the body wall in the body cavity and lateral to the oblique muscle fibers, They are usually arranged in parallel double rows, but occasionally they thin out to a single layer toward the dorsal and ventral mid-lines of the body cevity. The cells are similar in character to those of the head and hook glands, but do not stain as deeply. In the head region they are most prominent along the dorsal wall of the body cavity, and in many places are almost continuous with the cells of the head gland. They are quite uniforrn in size and average $0.016 \mathrm{~mm}$. in length. There is no duct or canal connecting them with any other structure.

Alimentary Pract. The alimentary tract is in the form of a long simple tube, varying in width and structure thruout its length. It has six divisions; (1) oral papilla, (2) mouth, (3) pharynx, (4) esophagus, (5) stomach, and (6) hind gut. The oral papilla marks its anterior termination and serves as an upper lip for the mouth, the actual mouth opening being a transverse slit leading into the pharynx from the posterior edge of the papilla.

The pharynx below the mouth is $0.02 \mathrm{~mm}$ in diameter and extends up and inward for a distance of $0.03 \mathrm{~mm}$. Its walls consist of a layer of epithelial cells lying beneath the cuticle and a number of muscular fiber bands. "T. Baldwin 

Spencer has suggested that the oral papilla is used by the parasite as a rasping organ, and that the pharyngeal muscles are employed to extend or withdraw it from the mouth opening. The fiber bards connect with the oral papilla and the border of the mouth. Leading away from the pharynx is a narrow tube like esophagus $0.018 \mathrm{~mm}$. in diameter and extending inward and down for a distance of $0.13 \mathrm{~mm}$. The layer of epithelial cells is continuous with that of the pharynx. Iight bands of both circuilar and longitudinal muscle fibers are present in the esophagus and the cuticle here becomes extremely thin. Toward its posterior end, it widens rapidly and leads into the stomach cavity. This is the widest portion of the alimentary tract, and attains a diameter of $0.15 \mathrm{~mm}$. in some of the larger specimens. The length of the stomach is $0.5 \mathrm{~mm}$. and the histological structure is quite similar to that of the esophagus, but here the epithelial layer is thinner and the cuticle vider. Coagulum is nearly always present thruout the length of the stomach. Leading from the stomach is the hind gut, which is quite uriform in size for the greater part of its length. It is $0.08 \mathrm{~mm}$. in diameter for a distance of $1.6 \mathrm{~mm}$. and then narrows to an average diameter of $0.52 \mathrm{~mm}$. for the remainder of its length. The columnar epithelium of the hind gut extends out further towards the center of the intestine than it does in the esophagus or stomach. A characteristic feature of the hind gut is its lateral turning and tristing. The bending stops however, as the posterior end is approached except for a short turn that 

leads to the anal opening. Accompanying the intestine, from a point near the head region, are two large cellular masses. The intestine is wedged between and connected with them by a light mesentery on either side. The glandular bodies are the hook glands.

\section{The Nervous System. The nervous system consists} of a central ganglionic mass, ventral to the lower end of the esophagus and two pairs of nerves given off from its upper and lower margins. The anterior pair leads directly to the primary papillae and end at the tip passing uprard thru the center of the primary papillae. The posterior nerves extend well toward the caudal end of the body and lie on the ventral side of the body cavity closely approximate to the oblique fibers. The latter nerves are present in all cross sections of the body posterior to the beginning of the stomach. In allied species, Stiles, Ieuckart and spencer have described a delicate clrcumesophaoeal ring and additional nerves branching from the main nerve mass. The writer was not able to locate the above mentioned structures in any of the sections available.

\section{Reproductive System. A study of the male repro-} ductive organs shows them to be in an undeveloped condition. They represent one of the early stages that Ieuckart has thoroughly described in Pentastomum taenioides (I. serrata). He tems it the "Fifteenth Honth" stage. The atrium genitale or genital aperture marks the anterior termination of the systern. It is the junction point of the two seminal tubes which branch out and extend posteriorly. They lie anterior 

and ventrad of the hind gut and approach in an oblique direction to two bag like structures which are directly ventrad of the hind gut. Each tube is $0.33 \mathrm{~mm}$. in length and composed of an inner wall of cells arranged in a single layer and an outside covering of transverse and longitudinal muscle fibers. On either side, the tube enters a rounded structure, which is divided into upper and lower portions. The upper portion is not as large as the lower part in this stage. It develops more rapidy later and pushes the lower pauch inwardy. The upper is known as the cirrus pouch or sac and conteins the cirrus, in the mature forms. The seminal tube also enters the cavity of the lower pouch which is called the dilator rod sac. The rod sac appears somewhat larger than the cirrus pouch. The lining of the two cavities is similar. A row of epithelial cells covers the muscular wall of each vessel and lines the cirrus bulb, a canal extending posteriorly from the dilator rod sac. The cirrus bulb is only the widening of a tube, the vas deferens, with which it is continuous. The vas deferens is $0.25 \mathrm{~mm}$. in length and its structure is that of a narrow canal with the walls lined on either side with several rows of small epithelial cells. At the end of this tube, the ejaculatory duct branches to the side and the vesicula seminalis continues as the principal prolongation of the vas deferens. The ejaculatory duct is $0.43 \mathrm{~mm}$. long, cylinarical in shape, and ends in a round cone. The wall of the duct is thick and muscular and stands out quite plainly in a surface view of the body. Immediately outside of the wall is a narrow row of rounded epithelial cells. The 


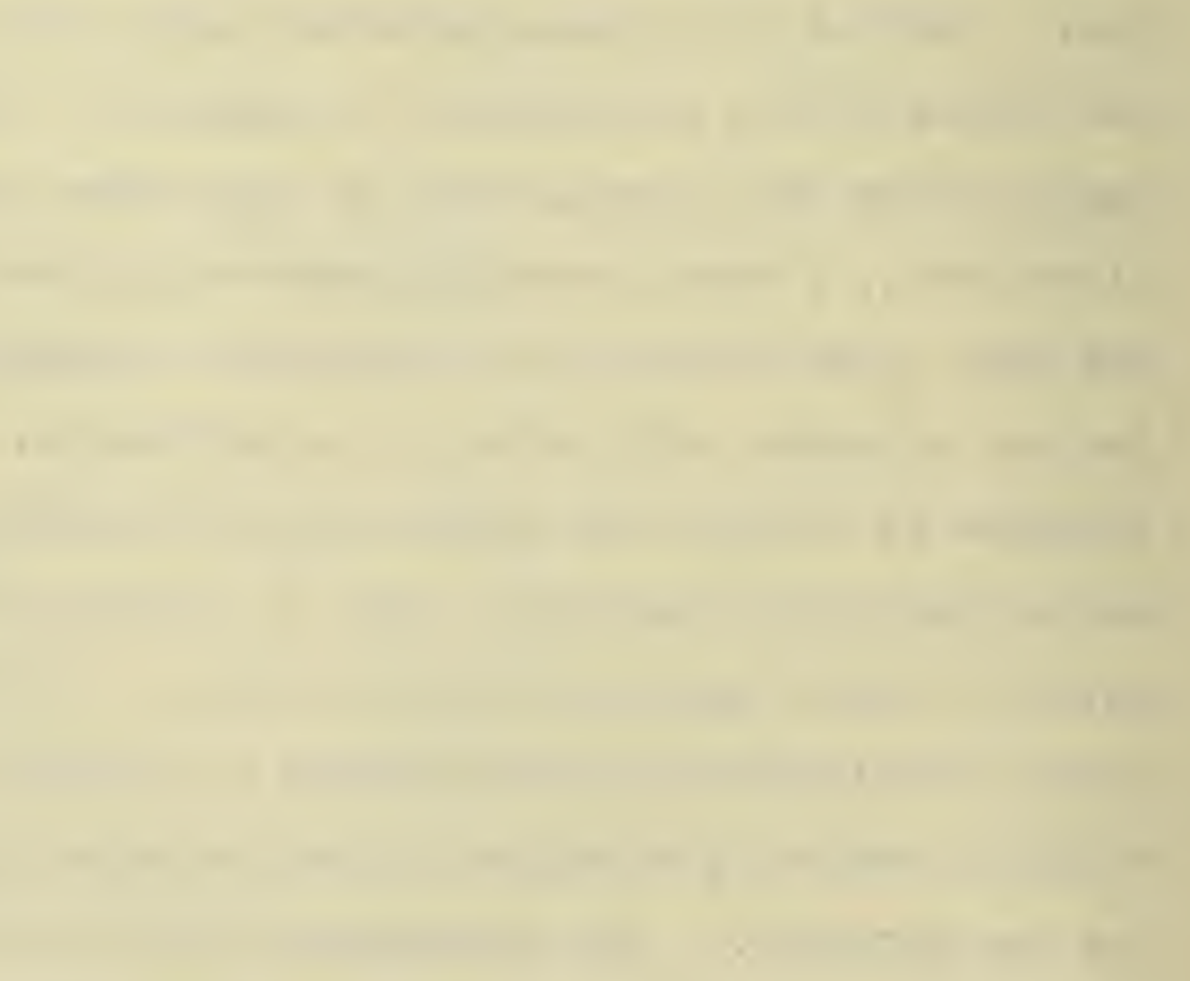


purpose of the duct is to aid in the expulsion of the cirrus. The pair of seminal vesicles meot just dorsal to the hind gut and enter the testis. The alimentary tract extends thru the ring formed by the two branches of the genital system, at a point about $0.2 \mathrm{~mm}$. anterior to the boginning of the testis. The testis is a long narrow unpaired tube extending a little more than half the length of the body and lying dorsal to the hind gut. In mature specimens, it is flattened alono its whole length except at the extreme anterior end. And in older specimens it is much larger, often taking up more space in the body cavity than the intestine. The material within the mature testis consists of numerous cells of doubtful origin scattered here and there, which are much larger than the cells of the testis' wall. In a few specimens bands or sheathes of sperms are present between the cells, bat in most cases no sperms were evident. The wall of the testis is composed of a minute outer membrene and an inner double row of deeply stained cells which have large nuclei 



\section{THE ENCYSTED LARVA}

In the material, some of the specimens are enclosed in a very thin elestic membrane which covers the body completely. The membrane is composed of connective tissue and is quite transparent so that the form of the body and even the outline of the hook glends are easily seen thru it. The marks of the annuli are just faintly noticeable. The cyst, formed by the membrane is $1.52 \mathrm{~mm}$. in diameter and the parasite lies coiled on itself. A circle is thus formed by the body but the anterior tip of the cephalothorax does not quite come into contact with the posterior end of the abdomen. The body lies on itg lateral edge with the ventral surface out and the dorsal surface is bent and forms the circumference of the inner circle. In some cases the posterior end of the body lies a little within the cephalothorax and here the central cavity is not so lerge. Examination of the larva shows the presence of the characteristic double hooks and the same number of annulations as in the free parasite. There is no apparent difference between the two states except the encysted form measures slightly less than the average length of the free larva. The intemal anatomy of the two larval types agree in all points. 



\section{IILE HISTORY}

As in other parasitic forms the problem of development ment in the Iinguatulidae is rather complex. Chiefly thru the researches of van Beneden, Leuckart and Stiles have the life histories of a very few species been worked out. In 1848, van Beneden was able to observe the development of Iinguatula diesingii ( $P$. crotali) and trace its life history. Leuckart later made a more complete study of Pentastomum taenioides (L: serrata) and proved Pentastomum denticulatum the larval stage. Stiles 1891 worked further on P. probscideum ( P. crotali) while Neumann 1899 has conducted experiments with P. ermillatus from the african python, Python sebae.

The life cycle of the parasite is divided into two periods, the adult and the larval period. However, many recognize several larval stages. The adult stage is usually found in the lung of snakes and other reptiles with the exception of a very few species. I. serrata for instance, has its adult stage in the nasal cavities of carnivora. The larval stages are most commonly found in herbivorous animals, but here agian we have exceptions to the rule. The larval stage of $P$. armillatus has been found in a number of carnitora. Sambon thinks that the iarger mammals are only accidental hosts and that the life cycle can not there be normally be continued. Encstment follows similar to that of bladder worms and the larval cysts of tape worms. The final result is the calcification of the cyst. But this is not always what happens. 

Larvae when not liberated from their cysts often begin a migration probably in an effort to reach the adult host. This migration may cause grave symptoms in the host for the presence of the larvae favors secondary bacterial infection. Too, their position and number may be sich as to further menace the life of the larval host.

The ova which may be as many as half a miliion are laid by the adult female in the nasal cavities of the host. They are either discharged thru the mouth or pass thru the alimentary canal with the snake'a excretions. In the case of dogs, they are sneezed from the nostrils. The intermediary host becomes infected in one of three weys, by swallowing embryos with or in the food, (2) thru drinking water, (3) by coming into direct contact with the ova. The ova are very resistent to climatic conditions. Stiles placed a number of eggs in a moist chamber for forty nine days and then sacceeded in infecting mice. Broden and Todhain has a similar experience. They kept the eggs of $P$. armillatus in water for three months and then were able to successfully infect animals. Two dogs in Neumann's laboratory were accidentally infected with linguatulid eggs from the Python sebae. The pythons had been dissected in the yard of the laboratory several months previous to the birth of the dogs. The ove therefore had been lying in the yard for many weeks, perhaps under severe weather conditions. Still they were able to infect the dogs. 

In the intermedicry host, the ovum after passing into the alimentary tract comes into contact with the gastric juice of the intestine and the shell covering is dissolved away. The four legged embryo becoming free attaches itself to the wall of the intestine and after a short period of growth, pierces thru the mucosa of the intestinal tract. If it happens to reach a lymph veseel, it makes its way to the mesentaric glands or else is carried thru the ductus thoracicus to the right heart and lungs. However, if the embryo comes into contact with the blood vessels of the intestine, it is transported to the venae porta and the liver. "Then the embryo comes to rest, a cyst is produced by the host. Here growth continues slowly until the embryo escapes from its cyst in the body of the adult nost or else calciilcation takes place. rnier certain conditions, a migration from the larval host taires place and the oarasites attempt to escape.

Certain species have only been found in the larval stage, while other forms are known to be present in both the larval and adult state in a single host. An examole of the complete development without a secondary host is found in $P$. oxycephalus where the two stages occur in the lungs of the alligator. The larva and the adud of $I$. serrata are both found in man. It is therefore probable that for some species, an intermediate host is not necessary in order to complete the life cycle. 

VII. SYSTEMATIC POSITION AND CLASSIFICATION.

In trying to identify some linguatulids, Shipley found great difficulty in arriving at any clear idae of the existing species of the family. He consequently published (1898) his paper entitled "An Attempt to Revise the Family Linguatulidae", in which he has sought to bring together all previously described species under his classifiction. In this paper, he raised the subgenera Iinguatula and Porocephalus to genera as Hoyle had suggested, In describing the different species, he has given Ieuckart's diagnosis in many cases because of the latter's valuable systematic work in the case of some forms where the authors description. was incomplete. Since shipley's paper, two new genera have been added to the family and many new species described. Sambon has also cleared up many points of difficulty with regard to synonymous forms. The writer has endeavored to review the original descriptions of as many species as possible. Using these and the papers of Shipley Sambon as a basis, the following key and classification of the known species of the family Iinguatulidae is presented.

Porocephalus crocidili has recently been described by Theeler (1915) from the crocodile of Ecuador. The diagnosis of this species is omitted because Wheeler's paper has not been available.

Raillietiella boulengeri sambon which is considered by some as a doubtful species, is included, altho without a complete description of the form. 


\section{.}


Key to Species of Linguatulidae.

A. Iinguatula Frohlich 1789.
$1-4(3)$
Body depressed, back raised, margins notched, body cavity extended into the lateral regions of the rings, pectinate. Hooks simple.
1. (2) Length less than $10 \mathrm{~mm}$... L. pusilla
2. (4) Length between 10 and $30 \mathrm{~mm}$.
2. (3) Length of female $18-27 \mathrm{~mm}$., caudal end greatly recurved......... I. recurvata
3. Temale 22.5 by $6.7 \mathrm{~mm}$... I. subtriquetra
4. Length of female over $50 \mathrm{~mm}$., ainuli $90 . .$.
... I. serrata

B. Reighardia Ward 1899.
5-8 (9) Body elongate, cylindrical, devoid of annulations, hooks poorly developed.
$5(6)$
Ho trace of annuli. ..
R. sternae
$6(7)$
Annuli occupying only one eighth of the circum-
$7(8)$ ference.
R. indicus
8
Length $13-17 \mathrm{~mm} . \ldots$
R. Johrmanii
Length $23 \mathrm{~mm}$, annuli 70.. R. platycephalus

c. Raillietiella Sambon 1909.
$9-13$
Female genital opening anterior, bifid posterior
termination, three vesicular protuberances around each hook pit.
$9(12)$
Length less than $30 \mathrm{~mm}$. , more than $20 \mathrm{~mm}$., hooks double.
9 (11)
Length $20-22 \mathrm{~mm} \cdot$, annuli $40-50 . \cdots$
R. furcocercum
10
Body nore slender than in (9) ...
R. boulengeri
11
Length $20-30 \mathrm{~mm}$., annuli $45-50 \ldots . .$.
mediteranneus
12
Length 30-40 mm., cephalothorax rounded, body thicker and lighter than in var. mediteranneus... R. farcocercum var. orientalis 

13 Length less than $20 \mathrm{~mm}$., hooks simple... R. geckonis

D. Porocephalus Humboldt 1811.

14-37 Body slightly rounded, body cavity continuous.

14 (23) Length less than $15 \mathrm{~mm}$.

14 (16) Length less than $10 \mathrm{~mm}$, hooks double.

14 (15) Length less than $5 \mathrm{~mm}$.

14 Length $3-5 \mathrm{~mm}$., annuli 50.. P. najae sputatricis

15 Iength $6.3 \mathrm{~mm}$, width $0.65 \mathrm{~mm}$., snnuli $58 . \ldots$

P. heterodontis

16 (17) Annuli less than 40.... P. pattoni

17 (19) Annuli 40-50.

I7 (18) Annuli 40-41... P. wardi

18 Annuli $45 . \ldots \ldots \ldots$ P. kachugensis

19 (20) Annuli $50-55 \ldots \ldots$ P. coarctatum

20 (21) Annuli $60-65 \ldots \ldots$. P. crocidura

21 (22) Annuli 70-90, anterior end pointed....

P. megastomus

22

Annuli 70-90, anterior end rounded....

P. Eracilis

23 (27) Length less than $30 \mathrm{~mm}$.

23 (25) Annuli 40-50.

23 (24) Outer hooks double.... P. subuliferus

24

Hooks simple.

P. megacephalus

25 Annuli $60-70$

25 (26) Cephalothorax wider than abdomen... .

P. seurati

26

Cephalothorax not wider than abdomen....

P. oxycephalus

27 (28) Length less than $40 \mathrm{~mm} . .$. P. tortus

28

Length of female over $40 \mathrm{~mm}$. 

28 (32) Annuli less than 35.

28 (30) Annuli 16-26.

28 (29) Annuli 16-22... P. armillatus

29 Annuli $22-26 \ldots \ldots \ldots$ P. grandis

30 (31) Annuli 20-30, groove between cephalothorax and abdomen P. annulatus

31 Annuli $26-33 \ldots \ldots$... moniliformis

32 (33) Annuli $35-45 \ldots \ldots$... P. clavatus

33 (35) Annuli 45-55.

33 (34) Annuli 50, hooks simple... P. globicephalus

34 Annuli 45-52, outer hooks double....

P. stilesi

35 (36) Annuli $65-70 \ldots . . \quad$ P. teretiusculus

36 Annuli 80 or more......

36 (37) Mouth on line with hooks.... P. crotali

37 Houth anterior to hooks.... P.Iari 

Diagnoses of the Known Spocies of Iinguatulidae.

(1) Linguatula pusilla Diesing 1836.

Body long, attenuated posteriorly, ventral part slightIy flattened, sub-elliptical, dorsum slightly convex, above and below the margins evidently folded transversely. Head truncated; mouth round, between the two muscle plates which are vertical, converging backwards. Bothria arranged in an arc, provided with simple hooks. Length $1 \frac{1}{2} "$, width $\frac{3}{4}$ ". (Leuckart) one of the smallest linguatulids.

Habitat. In the intestine of Acara coscudo from South America.

(2) I. recurvata Diesing 1836.

Body lance shaped, posteriorly attenuate and recurved, emarginate at the caudal apex, ventral surface slightly flat, dorsil convex, folded in ring fashion at the margins. Head truncate; mouth elliptical, placed betiveen the arcs of the bothria sheathing simple hooks. Length of female 18-27 mm. (Leuckart) Easily distinguished from I. serrata Jy the jifid ta1? which is always bent backwards.

Habitat. Frontal sinuses and trachea of Felis onca. Heart of peccary, Dicotyles labiatus from Brazil.

(3) I. subtriquetra Diesing 1836.

Body subtriangular, slightly flattened ventrally, subelliptical and ovate-oblong, folded transversely, margins crenate. Dorsal sides slightly convex. Head truncate, mouth orbicular, placed in the miale between the four oblique ventral ribs. Bothria arranged in an arc. Length of female $6.7 \mathrm{~mm}$. (Leucirart)

Habitat. Throat and lungs of Crocodilus sclerops Gray from south America. Also in the pharynz of the Indian crocodile.

(4) I. serrata Proelich 1739 .

Adult. Body lanceolate, posteriorly attenuate, postero-ventral part slightly fiat. Head rounded destitute of marks, cephalothorax not very distinct. Annuli about 90, single series of stigmata arranged at intervals in the modian line. Hoois perceptibly acuminate, adhering by an elongate fulcrum, sharply recurved. Female $80-100 \mathrm{~mm}$. in length, width at the anterior part of the body $8-10 \mathrm{~mm}$., at the posterior part $2 \mathrm{~mm}$. Wale $18-20 \mathrm{~mm}$. long, width $3 \mathrm{~mm}$. at the anterior part and $0.5 \mathrm{~mm}$. at the posterior part. (Ienckart) 
Habitat. In the frontal sinuses of canis familiaris, Equus caballus. Felis onca, and the nasal cavities of canis vulpes, Capra sp., Homo sapiens, Ovis aries, and the mulo.

Larva of I. serrata. Annuli dentate, accessory hook with boat shaped ternination, small end quite sharo. (Leuckart

Habitat. In the liver and mesenteric glands of capra sp.; the liver and lungs of the cat, and Cavia cutleri; the Iiver of Equus caballus; the lungs, mesenteric glands and intestine of Bos taurus; the lungs of Hystrix cristata, Lepus cuniculus, and I. timidus; the mesenteric glands of Camelus sp.,Ovis aries, Alcelaphus bulbalinus, Cervus dama, and lifus decumanus; the liver, connective tissue, spleen, kidneys and mesenteric glands of Ilomo sapiens. In the last named host. it has been reported from Brazil, Panama and many European countries.

(5) Reighardia sternae Nard 1899.

Body devoid of annulations, poorly developed hooks.

Habitat. Air sacs of the Bonapartes gull and the common tern, Iorth America.

(6) 3. indicus (v. Linstow) Sambon 1910.

Only females have been found. Rather young specimens are $20 \mathrm{~mm}$. long and $2 \mathrm{~mm}$. broad; behind the thin anterior end the body is thickened and spindle shaped, attaining a width of $1.18 \mathrm{~mm}$.; behind this it contracts to a narrow neck 0.79 $\mathrm{mm}$. in diameter; older animals are $24 \mathrm{~mm}$ long and $5 \mathrm{~mm}$. in diameter, the diameter here is nearly uniform. On the ventral side the cuticle is transversely ringed at regular intervals of $0.44 \mathrm{~mm}$., the rings occupying three twenty thirds of the circumference; the muscle fibers run in four direction transversely, longitudinally, and obliquely in two directions making equal angles with each other; the anterior and posterior ends are rounded. On the lateral edges of the tings there are posteriorly finger shaped prolongations, which become smaller and smaller further back, but which can be traced far backwards; exteriorly they possess an exterior chitinous covering; at the anterior end there lies beneath the cuticle an oval ring which is provided in front and behind with a prolongation and on the right and left of it with two hooks on each side which are directed forwards and outwards and the points of which project freely. Their lengt is $0.15 \mathrm{~mm}$. The intestinal canal opens at the posterior end; the vaginal aperture is situated closely in front of the anus; the vagina is $1.1 \mathrm{~mm}$. long and $0.044 \mathrm{~mm}$. wide, while the width of the uterus, the numerous convolutions of which 

fill the body cavity amounts to $0.16 \mathrm{~mm}$; the eggs possess a thick hyaline envelop, they are $0.052 \mathrm{~mm}$. long by 0.044 $\mathrm{mm}$. wide, the yolk attaining a length of $0.026 \mathrm{~mm}$. and a width of $0.016 \mathrm{~mm}$.

Habitat. In the trachea and lungs of Gavialis gangeticus from Asia.

(7) R. Iohrmanni Vaney and Sambon 1910.

Body of adult female club shaped, slightly flattened on the ventral surface; greatest width at the posterior limit of the anterior quarter, from this the body rapidly lessens in front, and more slowly behind. Length $13-17 \mathrm{~mm}$. greatest breadth $3 \mathrm{~mm}$. Hooks and mouth very small and closely compressed at the tip of the body. (Lohmann)

Habitat. In the lungs of lionitor niloticus, Varanus niloticus, and in the luns of the North African lizard Varanus ocellatus.

This species was desuribed by Ionfmann in 1889 as Pentastomum clavatum and renamed by Sambon.

(8) R. platycephalus (Lohrmann 1889) Sambon 1909.

Body of adult female almost cylindrical, greatest diameter just anterior to the hinder end. Head flat, blunt, and only slightly smaller than the body. Hooks slender, widerl separated from each other, the mouth opening distinctly oval, the long axis longitudinal, situated between the anterior hooks. About 70 rings are scircely visible. Length $23 \mathrm{~mm}$., breadth $2.8 \mathrm{~mm}$., hook glands consist of two glandular bodies attached to the alimentary canal. (Iohrmanr

Habitat. Unknom, perhars in the alligator.

(9) Railietiella fercocercum (Dies. 1836) Sambon 1909.

Body subfusiform, attenuated posteriorly, bifid at the caudal end, segmented with linear rings. Head obtusely triangular, somevhat depressed. Houth oval, has a wide margin with truncate apex and between the bothria a truncate cone obtuse trilobed in shape with double unequal hooks. Female, length 20-22 mm., width anteriorly $2.2 \mathrm{~mm}$., width posteriorly $1.12 \mathrm{~mm}$. (Leuckart) Annuli $40-50$.

Habitat. Iungs of Varanus ocellatus, Boa constrictor Amphisbaena alba, mesentery of zamenis constrictor, and abdominal cavity of Drymobius bifossatus. 

(10) R. boulengeri Vaney and Sambon 1910

Very similar to 2. furcocercum but more slender. Hiss Hett could find no essential difference between the two species.

(11) R. furcocercum var. mediterraneus Hett 1915

Male 10-15 mm. in length, female $20-30 \mathrm{~mm}$. in length, annuli 40-45. The body is more slender and darker than in var. orientalis.

Habitat. Zamensis gemonensis.

(12) R. furcocercum ver. orientalis Hett 1915.

Length $30-40 \mathrm{~mm}$., annuli 40 or more, mouth oval. Anterior end of cephalothoraz more rounded and the body more slender than in $\mathrm{R}$. furcocercum.

Habitat. Zamensis mucosus and Naia tripudians.

(13) R. geckonis Dujardin 1845.

Body fusiform, posteriorly attenuated, bifid caudal tip, segmented. Head triangular, hooks simple, unequal, posterior ones twice as large as anterior. Temale, length 16-18 mm., width $1.6-1.8 \mathrm{~mm}$. (Leuckart)

Habitat. Lungs of the Siamese gecko, Gecko verticillatus.

(14) Porocephalus najae sputatricis Leuckart 1860.

Body in larval stage cylindrical, posteriorly attenuated, acuminate. Cephalothorax hardy distinguishable, rounded at the front. ings about 50, very short, serrated, perforated by two row of stigmata arranged alternately. Fooks in pairs, unequal, the accessory being small. The principal hook is barb shaped, fulcrum wide, rather short, rounded; anterior holks smaller than nosterior; points of barbs curve nearly to the base. Iength $4.5 \mathrm{~mm}$., width $0.6 \mathrm{~mm}$. (Leuckart) The adult stage is unknown.

Habitat. Abdominal muscles and peritoneum of Iraja tripudians. 

(15) Porocephalus heterodontis Leuckart 1860.

Species observed orly in the larval stage. Cylindrical body, posteriorly attenuate, anteriorly clavate; front round; annuli 58, very narrow, fringed. Stigmata form a single series of openings. Hooks double, unequal, upper more slender, lower broader and sharply curved; basal hook broad, elongate, round. Length $6.3 \mathrm{~mm}$., wiath $0.65 \mathrm{~mm}$. (Leuckart).

Habitat. Encysted in the abdominal muscles and peritoneum of Heterodon sp. The writer reports this species for the first time from the water moccasin Ancistrodon piscivorus.

(16) P. pattoni Stephens 1908.

Body grayish white (spirit specimens), showing a separation into head, neck and body. The head is globular, flattened ventrally and rounded dorsally, and is separated from the body by a fairly distinct narrow neck. of some dozen specimens the longest was $11.5 \mathrm{~cm}$. while the shortest was $2.5 \mathrm{~cm}$., the majority measured $6-8 \mathrm{~cm}$. in length. The number of rings varies somewhat but avenages 36 . There are generally 2 rings on the head. The body is cylindrical, ends bluntly, and the posterior end exhibits some tortion. the thickness of the body is about $2.5 \mathrm{~mm}$. On the ventral surface of the head are two pairs of strongly curved rooks, similar to those of many other linguatulids. In front of the mouth hooks there are several small papillae, corresponding in position to the continuation of the clefts that contain the hooks. Between the hooks lies the chitinous opening of the mouth which has the shape of a horse collar. cutaneous pores are abundant on the head and on the ridges of the anterior part of the body, they then become indistinct and few are visible on the last segments. Eggs taken from the uterus measure 70 by 80 micra. (Stephensid

Habitat. In the lungs of the Indian rat snake, Zamenis V. Ptyas mucosus or Dhaman.

(17) P. wardi Sambon 1909.

Length $7-13 \mathrm{~mm}$, annuli 45. In form and general appearance resembles P. crotali. Larval form.

Habitat. Abdominal cavity of the great Teju or common Teguexin, Tupinambis teguexin from South America. 


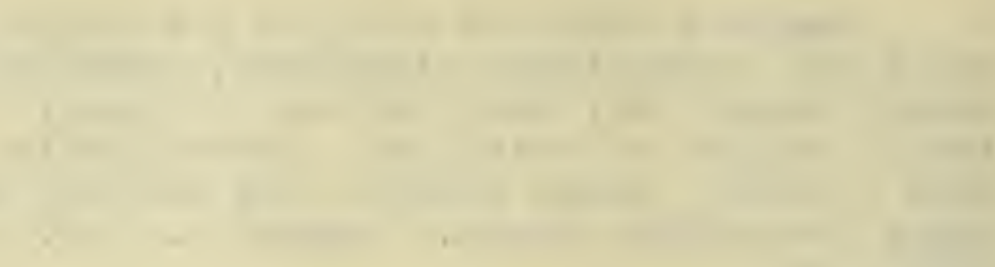

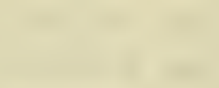

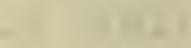


(18) P. Kachugensis Shipley 1910.

Specimens vary from $9-12 \mathrm{~mm}$. in length. Body club shaped, thicker anteriorly. The thicker anterior end is $3-3.5 \mathrm{~mm}$. from back to front, and $3-4 \mathrm{~mm}$. from side to side. The body tapers somewhat suddenly and the posterior two thirds is from $1-1.7 \mathrm{~mm}$. in breadth and a little less in depth. In their cysts the animals are coiled like a note of interrogation and the coil is always in one plane. Anteriorly the head bears a pair of well marked rounded papillae which project forward. The mouth is small amd is placed at about the level of the inner hooks which are slightly in front of those of the outer hooks. All four hooks project rather further than in most pentastomids and they are very markedlyf double. The number of annulations is 40-41. At both ends, but particularly at the anterior end, the lines marking the annulations are very faint, and it is difficult to decide exactly where the first begins and the last ends. There are no internal organs serially homologous with the annulations. The annulations are confined to the ventral surface, they cease suddenly a little way up each side of the body and seen from the dorsal surface, the animal is smooth and not ringed. (shipley). The demarcating lines between the annulations are made more prominent by bearing a row of 150-160 chitinous rods, somewhat sabre shaped There is a slight median ventral groove.

Habitat. In the liver of Kachuga Iineata Gray, one of the Indian and Burnese repres ontatives of the family Testudinidae.

(19) P. coarctatum (Dies. 1850) Sambon 1910.

Head constricted at the base, subhemispherical, ventral side slightly flat, body heavily segmented with annuli. (Diesing) Annuli 50-55.

Habitat. Iungs of Drymobius bifossatus, Coluber carais. Except in the number of annulations this species resembles P. pattoni.

(20) P. crocidura Parona 1890.

Cylindrical body, slightly tapering behind. Iength $10.5 \mathrm{~mm}$., breadth thruout anterior end of body $1 \mathrm{~mm}$. Body divided into 62 regular annuli, which slightly diminish in length posteriorly. The anterior end of the body for the length of five annuli is flattened and bears two papillae. The mouth is surrounded by a chitinous ring and four double hooks. Iach annulus bears two or three rows of cutaneous pores. The posterior end has a groove which gives it a bilobed appearance. The hooks are on a line with the mouth. (Parona) 


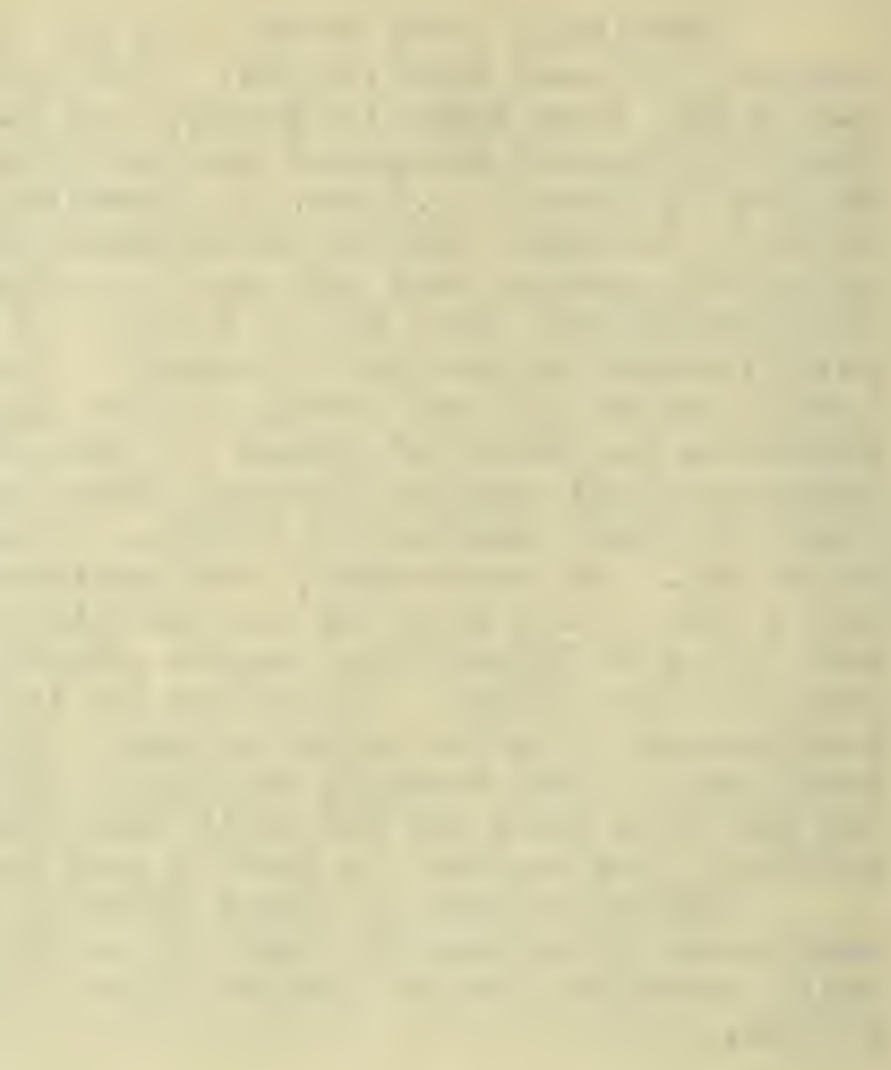


Habitat. In the peritoneum of Blyth's musk shrew, Crocidura fuliginosa from Burmah.

(21) P. megastomus Diesing 1836.

Body clavate, attenuately recurved, pointed, folded with linear rings, muscle plates. Iength of female $11 \mathrm{~mm}$., anterior wiath $2.2 \mathrm{~mm}$., posterior wiath $0.7 \mathrm{~mm}$.

Habitat. Iungs of Hydraspis geoffroyana.

(22) P. gracilis Diesing 1836.

Body slender in larval form, worm like, rings plicate, ventr 1 surface slightly flattered. Cephalothorax clavate, truncate, quite distinct, annuli 90, anterior narrow, posterior very narrow, border of body dentate. Stigmata collected together into four or five series, alternately disposed. Hooks elongate, two pronged, subequal, accessories joined closely with the main hook. Base broad, elongate, circular. Iength $11 \mathrm{~mm}$., width $1.7 \mathrm{~mm}$. Adult stage unknown. (Leuckart)

Habitat. Free in the body cavity or encapsuled in the visceraor mesenteries or muscles of the following South American fishes and reptiles. Fishes listed by Parona; Acara crassipinnis (Hydrogonus ocellatus). Bagrus pemecus (Arius sp.), Bagrus mesops (Arius hertzbergi and A. mesops). Macrodon trahira, Salminus brevidens, Tetragonopterus argenteus, Pygocentrus piraya (Serrasalmo piraya). Raphiodon vulpinus (Cynodon vulpinus), Pimelodus megacephalus, P. vituga, P. pirinampus (P. typus), Phractocephalus hemilopterus, Platystoma tigrinum, P. platyrhynchus

(Hemisorubim platyrhynchus), Pellona castelleana (P. flavipinnis), Symbranchus marmoratus, Gymnotus electricus, Carabus brachyurus (G. fasciatus), Sternarchus albifrons and Taeniura motoro. Reptiles listed by Diesing; Podinema teguixin (Tupinambis teguixin), Podinema sp., Bothrops juraraca (Lachesis lanceolatus), Elaps sp.. Pseuderis sp., Tropidonotus sp., coluber sp., Eunectes scjtale (E. murinus). It has also been taken from the intestine of : Iligator mississippiensis, the Horth Americen alligator. This species appears to be very common in Brazil. The Diesing collection in the Natural History wuseum of Vienna contains over 40 vials of these forms, collected by iatterer. About one half the specimens are one half the size given in the diagnosis. 

(23) P. subuliferus Leuckart 1860.

Body cylindrical, clavate at the ends, obtuse, segmented, cephalothorax very distinct, ventral part slightly flat. Rings about 40, short, slightly prominent, stigmata arranged in two irregular series. Hooks unequal, posterior double, anterior large single very short fulcrum wide. incurved, barb large, strong and distinguished by circular depression at the basal part. Accessory hook slender. Length $26 \mathrm{~mm}$., width $1.5 \mathrm{~mm}$. (Leuckart)

Sambon has found immature specimens to measure 9-15 $\mathrm{mm}$. in length. The head is separated from the abdomen by a complete groove. There is a midventral line and the outer hooks are double. Annuli 40-50.

Habitat. Adult. Lungs of gaboon puff adder. Bitis gabbonica, and lungs of Egyptian cobra, Naja haje. Type specimens' in the museum of the Liverpool School of Tropical Medicine.

(24) P. megacephalus Baird 1853.

Female, body yellowish white, somewhat depressed and terminating anteriorly in a large thick club shaped head. Dorsal surface depressed at the edges, rounder and very prominent in the center and transversely indged. Ventral surface is more flattened, ridged and wrinkled, with the mouth in a hollow depression, surrounded by four strong. brown simple hooks. The part of the body immediately beneath the head is very strongly ridged transversely, each of the first six six ridges wavedly wrinkled. Length 11 lines. Head is five lines $3 r o a d$, and the middle portion of the body about 3.5 lines long, diminishing in size toward the tail. The oviduct is very long, the portion outside of the body being two inches in length.

Male, length 14 lines, covered with a smooth skin which is slightly ridged across, and has at its anterior extremity a small sharp papilla about $\frac{3}{4}$ line in length and brow at the tip (the penis?). The inferior extremity is rounded more than in the fomale, but otherwise they are alike. (Baird) Annuli 40-50:

Habitat. In flesh of head of soonderbund crocodile, Crocodilus palustris from India.

(25) P. seurati Neveu-Lemaire 1900.

Body cylindrical, tapering gradually towerd the posterior end. Cephalothorax distinct and much wider than the rest of the body. Hooks unequal. The anterior pair are further out from the median line, mouth between and a little below the posterior pair. The mouth is in the form 


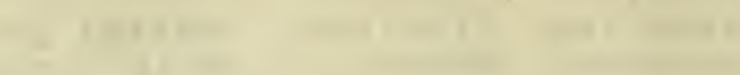

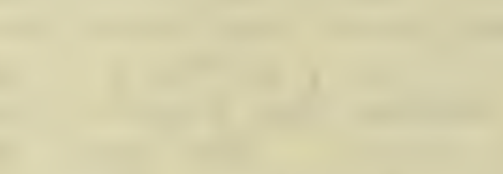

(n)
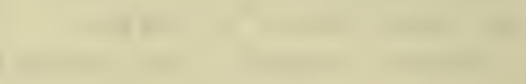
of a circular depression, in the background of which there appears a horn like armature. The abdomen is formed of 60 annuli, distinctly separated from each other, and extending to the posterior termination which is round. (Neuveu-Lemaire) Total length, $24 \mathrm{~mm}$., length of cephalothorax $2 \mathrm{~mm}$., width of cephalothorax $2 \frac{1}{2} \mathrm{~mm}$. average width of body $1 \frac{1}{2} \mathrm{~mm}$. , width of posterior end $\frac{3}{4} \mathrm{~mm}$.

Habitat. Underneath the skin in the superficial muscles of Elaps fulvius $I$. from Guatemala

(26) P. oxycephalus Diesing 1836.

Body cylindrical, straight or (in the smaller ones) incurved, ring folded, folds disappearing with increasing size. Cephalothorax very slightly distinct, anterior region acuminate, truncate rather prominent front. Wiath of abdomen posteriorly decreasing in the smaller and increasing in the larger forms. Anal extremity truncate. Rings about 60 , short lengthwise, provided with a single series of stigmata. Curvature of barbs approaches to base, apex almost straight; basal part in smaller specimens inflated, spined, in the largest,entire. Fulcrum wide elongated, rounded, orifice of mouth narrow. Iength of female up to $25 \mathrm{~mm}$., maximum wiath $3.4 \mathrm{~mm}$. Wale much smaller, length $10 \mathrm{~mm}$., width anteriorly $1.7 \mathrm{~mm}$ amd posteriorly $1 \mathrm{~mm}$. Larval stage. Body slender subfusiform, incurved, hooks double, fringes at the posterior margin of annuli. Slender barb shaped accessory hook. Spines slender, rather short, widely separated from each other, entirely absent on the posterior part of the body. Length $7 \mathrm{~mm}$., width $0.8 \mathrm{~mm}$. (Leuckart)

\section{Habitat. Adult and larva. In the lungs of} Crocodilus americanus, Caiman latirostris and C. sclerops; and in the lungs and liver of Alligator mississipoiensis.

(27) P. tortus shipiej 1898.

The young :orm is vory aisininctly ringed, the number of rings is 25 . In the mature forms the development of the genital organs have so stretched the skin that the rings have disappeared, and at the same time the body has become cure disappeared, and at this characteristic feature has suggested the specific name of the form. The cephalothorax which includes the first three or four rings, is well marked off from the rest of the body. The rings is the body stretches, disappear lastly from the region behind the well marked neck. The hooks are single, the inner pair slightly in advance of the outer. The mouth is almost oval and a little posterior to the inner hooks, a chitinous half cylinder runs back from it along the posterior face of the esophagus. The length of the mature female is $40 \mathrm{~mm}$., 

the head is $5 \mathrm{~mm}$. long. The width of the body is very constant behind the neck, tapering only slightly toward the tail, it is $2.5-3 \mathrm{~mm}$. The length of the immature female is $35 \mathrm{~mm}$., length of the young form $10 \mathrm{~mm}$., breadh $1 \mathrm{~mm}$. (Shipley).

Habitat. Dipsamorphus irregularis, from $\mathrm{New}$
Britain.

(28) P. armillatus Tyman 1847 .

Body thick, wide, transversely ridged, cephalothorax not very distinct, rounded anteriorly, abdominal rings 19 211 except the last equal in width, funnel shaped, posterior margin prominent and raised. Anal ring conical, acuminate. Female length $70 \mathrm{~mm}$., width $6.7 \mathrm{~mm}$. liale unknown. Larval stage probably is Pent. diesingi van Beneden from the peritoneum of Cynocephalus maimon, in capsules. Shape of body and number of rings agree, it differs only in size, being $15 \mathrm{~mm}$. long by $2.5 \mathrm{~mm}$. wide. Raised stigmata crowded closely and are dispersed in irregular series of eight or nine in a row. Margin of rings prominently dentate; no accessory hook. Fulcrum somewhat short, wide, truncated nosteriorly. (Leuckart)

Additional characters noted by Sambon. Annuli 16-22, length $9-13 \mathrm{~cm}$., width $5-9 \mathrm{~mm}$. He described the male as $3-4.5 \mathrm{~cm}$. in length and $3-4 \mathrm{~mm}$. in wiath. No difference between cephalic and abdominal regions. Two prominent oapillae above the inner hook pits, one above each. other small papillae below the inner hook pits, abore and below the outer hook pits, and at the back and side of the cephalothorax. In the female the vagina lies $2 \mathrm{~mm}$. anterior to the posterior end of the terminal cone. The male reproductive opening is in the midventral line, on the first anterior annulus. The nymphal form resembles the adult and has been found only in mammals.

Habitat. This is the most common linguatuli of the African region, and the larval form has beon found in the natives of North and Central Africa. Adult found in Bitis gabonica Dum. and Bibr., the gaboon puff adder; 3 . nasicornis Shaw, the horned puff adder; B. arietans Merrem; Python sebre Gm. of Test Africa; and P. regius Shew, the royal python. Larvae found in the liver of Hono sapiens and mesentery of lacacus; in the liver, spleen, intestine, stomach, peritonuem, mesentery and uterus of the common antelope, Tragilaphus scriptus, and in the antilope. Cephalopus leucogaster; it also is reported from Cricetomys gambianus, the Gambian pouched rat; Cerropithicus engythithia; Papio sphinx I., the Guinea babson; Perodicticus potto Gm.; Crossarchus obscurus; Cervicapra arundinum Bodd., the South African Reed buck; Camelopardalis giraffa I.; papio marnon, the mandrill; Cercopithecus albigularis sykes, 

Anthropopithicus troglodytes Gm., the chimpanzee; Cercopithecus pousarguei; Cercocebus fuliginosus Geoffr., the sooty mangabey; Erinaceus aethiopicus, the African hedgehog; Crossarchus fasciatus Desm., the banded ichneunon; Proteles cristatus Sparm., the aard wolf; and Nelis leo I.

(29) P. grandis Hett 1915.

Body cylindtical, tapering toward the posterior end; 22-26 annuli, not sharply defined. Hooks simple and together with the mouth lie in a pit bordered by papillae. Nouth circular. The posterior annulus is small, conical, and bears the transverse anus. Stigmata over the entire body surface. Small lobe in front of the mouth. Slight projection in the median line of the postero-ventral margin of each annulis. Wale $30 \mathrm{~mm}$. in length, female $82 \mathrm{~mm}$. in length. Miale genital opening directly in front of the anus on the posterior segment.

Habitat. In African vipers; Bitis gabonica, Cerastes cornutus and Bitis nasicornis.

(30) P. annulatus Baird 1853.

Body elongate, cylindrical, ribued transversely in adult females, cephalothurax clavate, rounded anteriorly, abdomen made up of 20-30 rings. Stigmata are found placed close together over almost the entire surface of tine rings forning eight to eleven series diminishing perceptibly posteriorly. Fulcrum wide, somewhat short, truncated posteriorly. Length of female up to $94 \mathrm{~mm}$., width $4-5 \mathrm{~mm}$. Smaller examples, $15-20 \mathrm{~mm}$. long and $1.8-2.3 \mathrm{~mm}$. wide. They have bands of rings which are hardly so prominent. Male forms agree in shape and size with the smaller females. (Leuckart). The annuli are separated from the head by a distinct groove.

Habitat.

Adult in the lungs of the Egyptian cobra, Naja haje. Larvae in the gray headed gallinule Porphyrio popphyrio, and the dernoiselle crane, Anthropoidas virgo from North Africa.

(31) P. moniliformis

Body thick tapering posteriorly, caudal extremity acuminate, contracted in moniliform fashion. Annuli 26-33. fale, length 18-25 mm., width $1.8-2.5 \mathrm{~mm}$. Genital opening is in the anterior midventcal line of the first annulus. Female, length 70-91 mm., width 4-7 m. Genital opening on terminal cone, $1 \mathrm{~mm}$. from the conus. 

Habitat. In the lungs of the Injlan pirnon, "hython molurus $\tau_{\text {. }}$, and the netted python, P reticulatus Schneid. from lialay.

\section{Larva of $P$. moniliformis.}

Specimens $17-20 \mathrm{~mm}$. in length, straight, elongate, acuminate, with nearly conical apex and an obtusely truncated head which is $2.5 \mathrm{~mm}$. in width. It is closely annulated with 30 rings, each of which is sharply defined and separated from its neighbors by a sharp edged, square profiled furrom. These rings from being very wide posteriorly $10.7 \mathrm{~mm}$. , become vey narrow in front and cease to be distinct at the head. The mouth has two lateral chitinous lio ridges, one on each side. The tro pairs of hooks are elongate, acute, with longer basal fulcra than in $P$. crotali (four times the length of the erserted portion of the hook), but with a much shorter basal process. The surface of the skin is covered over with numerous irregularly arranged circular dots with depressed edges, these are most numerous about the head and forepart, but become fewer posteriorly. (Nacalister).

\section{Habitat. In the peritoneal cavity of the large} Indian otter, Lutra noir, from the river Indus. The larva has been reported also from the liver of $\mathrm{H}$. sapiens from the Philippine Is., the samll intestine of $\mathrm{H}$. sapiens from the Dutch Indies, and tine submucous tissue of the jejunum of $H$. sapiens from India. It occurs in the mesentery, spleen, omentum and gall bladder of the Indian civet, Viverricula malaccensis Gm.; in the peritonuem and onentum of the macque monkey, Hacacus cynomologus from Indo-China and in the rhesus monkey, M. rhesus Aud.

(32) P. clavatus Tyman 1845.

Adult yellow tinged during life and gray white when preserved. Body claviform, elongate and more or less recurved. Anterior extremity rounded, somewhat flattened ventrally, and strixingly gibbous on the dorsal aspect. The tapering posterior portion terminates with a slight bulb like conical expansion. Cephalothorax 1.5-2 mm. long, rounded anteriorly, slightly convex, flat or concave on the venttal surface, prominently convex on the dorsal surface. Mouth oval. Hooks equal in size, sharply recurved and with robust points, longitudinally striated and $\frac{1}{2} \mathrm{~mm}$. long. Inner hooks simple, outer hooks provided with accessory spize. Annuli 35-45. Female 45-90 mm. in length, 1.27-4.5 $\mathrm{mm}$. in width. Anal and genital orifices open conjointly in a subterminal slit on the midventral surface, with its long axis transverse to that of the body. Niale, length 19-40 mm., width $1.3-3 \mathrm{~mm}$. Genital opening on the first or second anterior annubis, forming a cone on the midventral 

surface which is tipped with three papillae, two anterior and one posterior.

Habitat. In the lungs, trachea, and body cavity of Boa constrictor I., and lungs and hody cavity of Boa imperator from Central and South America.

Larval form of P. clavatus.

Body subcylindrical, curved one third or one half a circle, dorsum convex, ventrum concave, posteriorly rounded and constricted a short distance from the rounded extremity. Color white, opaque. Composed of forty or fewer annuli. Head posteriorly convex, anteriorly plain or slightly concave; mouth nearly round; hooks simple, situated in a curved line of which the mouth forms the center. Whole length 3-5 lines, breadth three fifths of a line; annuli generally' one eightieth of an inch wide; mouth one two hundredth of an inch in diameter; hooks one twohundredth of an inch long.

Habitat. Encysted in the liver of the Virginia oppossum, Didelphys virginiana Shaw, and the philander oppossum Philander philander L.

(33) P. globicephalus Hett 1915.

Female $50 \mathrm{~mm}$. long and has 50 annuli. Hooks simple and sharoly curved. Fiouth pear shaped with pointed anterior end. Head globulur and divided from the body by a well marked neck. Anus is a wide transverse slit on the terminal segment. Greatly resembles P. pattoni Stephens, differs in number of annuli and position of anus.

water mocassin.

Habitat. Tropidonotus fasciatus, North American

(34) P. stilesi Sambon 1909.

Greatly resembles $P$. crotali and $P$. clavatus in general form and appearance, but the posterior terminal ending is more rounded and the bodj is more uniform in diameter. Annuli 45-52. Outar hooks measure $\frac{1}{2} \mathrm{~mm}$. in length and are provided with a straight pointed accessory spine. The inner ones are simple and slightly larger. The mouth is ovoid with the narrow end foremost. Female $80-96 \mathrm{~mm}$., width $4-6$ $\mathrm{mm}$. On the midventral line there is a subterminal transverse slit $1 \mathrm{~mm}$. in length for the genital and anal openings. Male length $30-38 \mathrm{~mm}$., width $1 \frac{1}{2}-4 \mathrm{~mm}$. Genital opening in the first annulus.

Habitat. 

cavity of the bush master, Lachesis mutus, and the rat tailed pit viper, I. lanceoletus. The larval form is unknown.

(35) P. teretiusculus Baird 1862.

Head round and truncate, body cylindrical, of a red color, and considerably more attenuated posteriorly. Tail shortiy bilobed; greatest width of body about $4-5$ lines below the head. It then gradually attenuates until it, reaches the posterior extremity. Integument annulosely ringed, rings about one third of a line in width. Length 2 inches five lines, breadth three lines. (Baird) Immature females measure $12 \mathrm{~mm}$. in length; annuli 60-70; anterior half of each annulus is spotted, posterior half not; mouth triangular with folded corners; primary papillae two, anterior to inner hooks, secondary papillae seven pairs, three dorsal, two lateral and two ventral. Male, length $13 \mathrm{~mm}$., width $2 \mathrm{~mm}$. Genital opening oval, with raised lip on third and fourth annulus. An eighth pair of secondary prpillae lie just in front of the genital pore. The pointed tail is a fecture of the genus.

Habitat. Wouth of Australian snake, Hoplocephalus superbus and lungs of Pseudechys porophyriacus and Diemenia psammophis var. recticulata, the "Vest Australian spinifex snake.

(36) P. crotali Humboldt 1808.

Length of female $40-65 \mathrm{~mm}$., wiath $2-8 \mathrm{~mm}$.; the male is smaller; annuli over 80 . Mouth on line with the hoolss. Two prominent papillae above the oral opening. Houth club shaped, widest at the anterior end. Tapers to the posterior end where it somewhat enlarges, and then terminates in a short conical point. (Sambon)

Habitat. Adult, Crotalis terrificus Laur., the dog faced rattle snake from Venezuela; Crotalis horridus $\mathrm{L}$., the timber rattle snake; C. terrificus Beauvois, the diamond backed rattle snake; Spilotes pullatus iagler; and Lachesis lanceolatus I., from 3razil. Larva in Harmosa murina I., the murine opossum from Brazil.

(37) P. lari hegnin 1883.

Cylindrical, posterior end curved, and stouter than the anterior end which tapers. Rings are marked by slight undulating striae. Two lateral and terninal tubercules on the head. Mouth oval, situated in the anterior limbs of a cross like chitinous armature. In the left angle of this cross is a small sucker like disc. The inner pair of hooks 

are on the second annulus, the outer on the third. Female, length $6 \mathrm{~cm}$., bresdth $3 \mathrm{~mm}$. llale not quite $1 \mathrm{~cm}$. Iong and $1 \mathrm{~mm}$. in diameter. (Megnin)

Habitat. In the air sacs of Larus glaucus Brunn from polar seas, and in the air sacs of $I$. dominicanus licht from Bay Reo, Brazil. The larval stage is unknown, but Shipley thinks that it may reasonably be expected that its host is a fish.

The larval form of the species described by Diesing 1836 as Pentastomum oxycephalus resembles in a great many iespects the species under observation. The two agrec in the following: the number of annuli, position of the stigmata, the size, shape and arrangement of the spines, the structure and position of the hooks, the general shape and conformation of the body, the number and arrangement of the papillae, the position and structure of the mouth and genital apertures, and all points in the internal anatomy. Only in length of body is there a slight difference, Diesing's specimens being on the average a little longer. His neasurement for the length of $P$. oxycophalus is $7 \mathrm{~mm}$. The matter of the length, in this case, is not of great importance for the forms under discussion are probably in a more undeveloped stage than were the parasites described by Diesing. In addition, a further reason for believing the forms identical, is the fact that in both cases the alligator is the host. The specimens of Diesing are from the South American alligator but Chatin 1882 came across them in Alligator mississippiensis. In 1863 iedl found a small variety P. oxycephalus var. minor in the ivile crocodile and has given a good account of its internal anatomy. Leuckart has also discussed this species to some extent. The observations of these writers has confirmed the belief that the species studied by the writer is none other than P. oxycephalus, now known as Porocephalus oxycephalus Diesing 1836. 

VIII. Bibliography

Breinl, A, and Eindle, $\mathrm{E}$.

1909. A New Porocephalus. Ann. Frop. "Wed. and Paras.,2:321-322, 2 figs.

Broden, A. and Rodhain, J.

1908. Contributions a l'etude de Forocephalus moniliformis. Ann. Trop. lied. and Paras., $1: 493-504,1$ pl.

1910. Contributions a l'etude de Porocephalus armillatus. Ann. Trop. Med. and Laras., $4: 167-176$

Chatin, J.

1882. Notes antomigues sur une Iinguatule observee l'aliigator lucius. Ann. des. Sc. Nat. Zool. Ser. 6, 14tio. 2!:1-30, pl. 14.

Darling, S. $\mathrm{S}$, and clark, H. C.

1912. A Note on the presence of Iinguatula serrata Froelich 1789 in man in central America. Arch. Int. I"ed., 9:401-405.

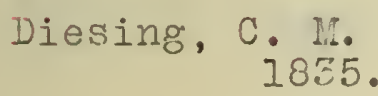

Versuch einer monographie der Gattung Pentastomen. Ann. Vien. Ius. $4 \mathrm{pl}$.

De Faria, Gomes, and Mrevassos, Lauro

1913. Irota sobre a presence da larva da ling. serr ta Froelich no intestimo do homem, no Brazil seguida de not:s sobre os linguatulideos da colccao do Instituto. liem. Inst. Oswaldo Cruz, 5:123-128, $1 \mathrm{pl}$.

Herzog, H. and Hare, C. B.

1907. Dorocephalus constrictus in a native rilipino. Trans. Amer. Ficr. Soc.,27:41-45.

Hett, Ii. I.

1915. On some new Eentastomias from the coological Societ 's Garders, Iondon. Eroc. 2001. 3०oc.,1:115-121.

Hoyle, W.

1884. On a new species of entastomum (P. protelis)

from the mesentery of Iroteles cristatus, with an account of its anatomy. rrans. Roy. Soc. vin., 32, vt. 1:165-193.

Johnston, T. H. and Cleland, J. B.

1911. A note on the occurrence of pertastomes in Australian cattle. Jour. Proc. Roy. Soc. II. S. "ales, 44:315-18. 

Leidy, J.

1904. Researches in Helminthology and varasitology. Smithson. Iisc. Col., iash.(1477) 46:I-28I.

Ieuckart, R.

1860. Bau und Entvickluigichichte der Eentastomen. Leipzig und Heidelberg, 6 pl. Linstow, 0. von
ig06.

Parasites from the Gharial. Jour. and Proc. Asiatic Soc. Bengal, 2:269-271, I pl.

Lohrmarin, 3 .

1889. Untersuchungen uber den anatomischen Bau der Pentastomen. Berlin. $1 \mathrm{pl}$.

Nacfie, J.W. S. and Johnston, J. E. L.

1913. A note on five cases of Porocevialiasis in man from Soutrern Ifigeria. Lancet, 185:13871389 , 1 fig.

N.⿲egnin, $P$.

1883. Note sur les Helminthes. BuII. Soc. Zool. France, 8:153-156, I pl.

Neumann, G.

1899. Sur les Eorocephalis du chien et de quelque mammiferes. Arch. Faras.,2:356-361.

Neveu-Lemaire, li.

1900 .

Description d'une nouvelle especie de

lingustule. Bull. lus. lat. Hist. Iaris, 1:111-112, 1 fig.

Farona, C.

1890.

Sopra due Specie di Pentastomum. Ann. Ius. Stor. Nat. Genoa, Ser. 2, 9:69-78.

Sambon, I. i.

1909. Remarks on Drs. Breinl and Hindle's paper on a new Forocephalus. e'our. 'rrop. Med. and Hyg. , 12:99.

1909. Remarks on Drs. Broden and Rodhain's paper on 'Porocephalus moniliformis'. Jour. Trop. Hed. and Hyg., 12:79-81.

1910. Porocephalus in man, I, II, III. Jour. Mrop. INed. and Hyg.,13:17-24, $212-217,258-262$.

1912. Porocephalus in tran, IV, V. Jour. Trop. lied. and Hyg., 15:321-327, 371-774.

1913. Forocephalus in man, VI. Jour. Trop. lied. and Hyg., 16:98-100. 

Shipley, A. E.

An attempt to rerise the fumily inguatulidae. Arch. Paras., 1:52-80.

1910. Report upon two small collections of Pentastomids with the description of a new species of Porocephalus. Faras., 2:275-278, $1 \mathrm{pl}$.

Epencer, $\pi$. B.

1892. The Anatorny of Pentastomum teretiusculum Baird. Quar. Jour. Hicr. Sc.,34, pt. 1,:1-75, 9 pl.

Stephens, J. W. W.

1908. A new Iinguatulid, Porocephalus pattoni. Ann. Mrop. lied. Piras.,1:553-554.

Stiles, Ch. W.

1891. Sur la biologie des Iinguatules. C. R. hebd. Sennces et liem. Soc. Biol.,3:689-691.

1891. Bau und Entwicklungsgeschichte, Ientastomum proboscideum, Fud., und Fentastomum subcjlindricum Dies. Zeit. f. viss. Zool,3:89164, $\therefore \mathrm{pl}$.

1893. On trr recent occurrence of Iinguatula rhinaria Railiet 1886 , and raenis echinococcus $v$ Siebold 1853 in the United States of liorth America. mrans. Fan-kmer. Ired. Congr.,:1163-1165.

Ward, H. B.

1899. On Reighardia, 8. new genus of Linguctulid. Proc. Amer. Ass dv. Sci.,48:254.

1900. Arachrids. Wood's Ref. Hanabook of Ined. Sci. $1: 428-423$.

Wedl, K.

1863. Zur He?minthen fauna Agyotens. Sitz. Kais. Akad. viss., 48, pt. 1, Art. 408: 1-8, 1 pl. 

IX. EXPLANATION OF THE PLATES.

$$
\begin{gathered}
\text { Explanation of Plate } \\
\text { Plate I. }
\end{gathered}
$$

Lateral view of mounted specimen, showirg alimentary tract; $\times 173$ 



$$
\text { (2) }
$$





\section{Explanation of Flate \\ Elate II.}

Abbreviations.

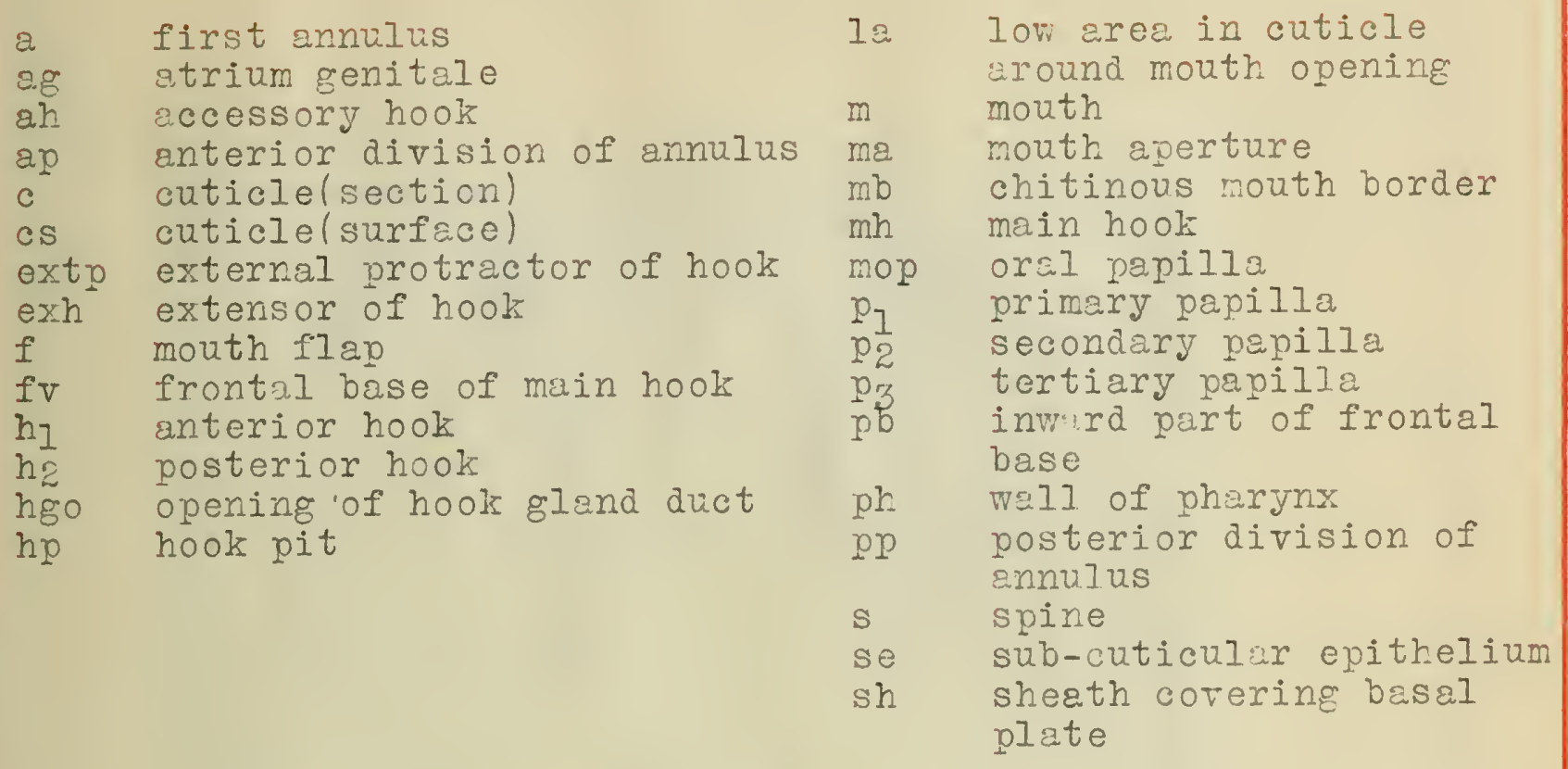

Fig. 2. Ventral view showing arrangement of papillae;

x 180 .

Fig. 3. liouth, ventral view; $x 400$.

Fig. 4. Lateral viev of left anterior hook with part of the attached muscles; $x 400$.

Hig. 5. Lateral view of primary papiljae; x 400

Iig. 6. Lateral view of edge of body shoving

Rivisions of the annuli; $x 230$

Fig. 7. Cross section of cuticle in spinous region;

x 800 .

Iig. 8. Atrium genitale; x 400 . 



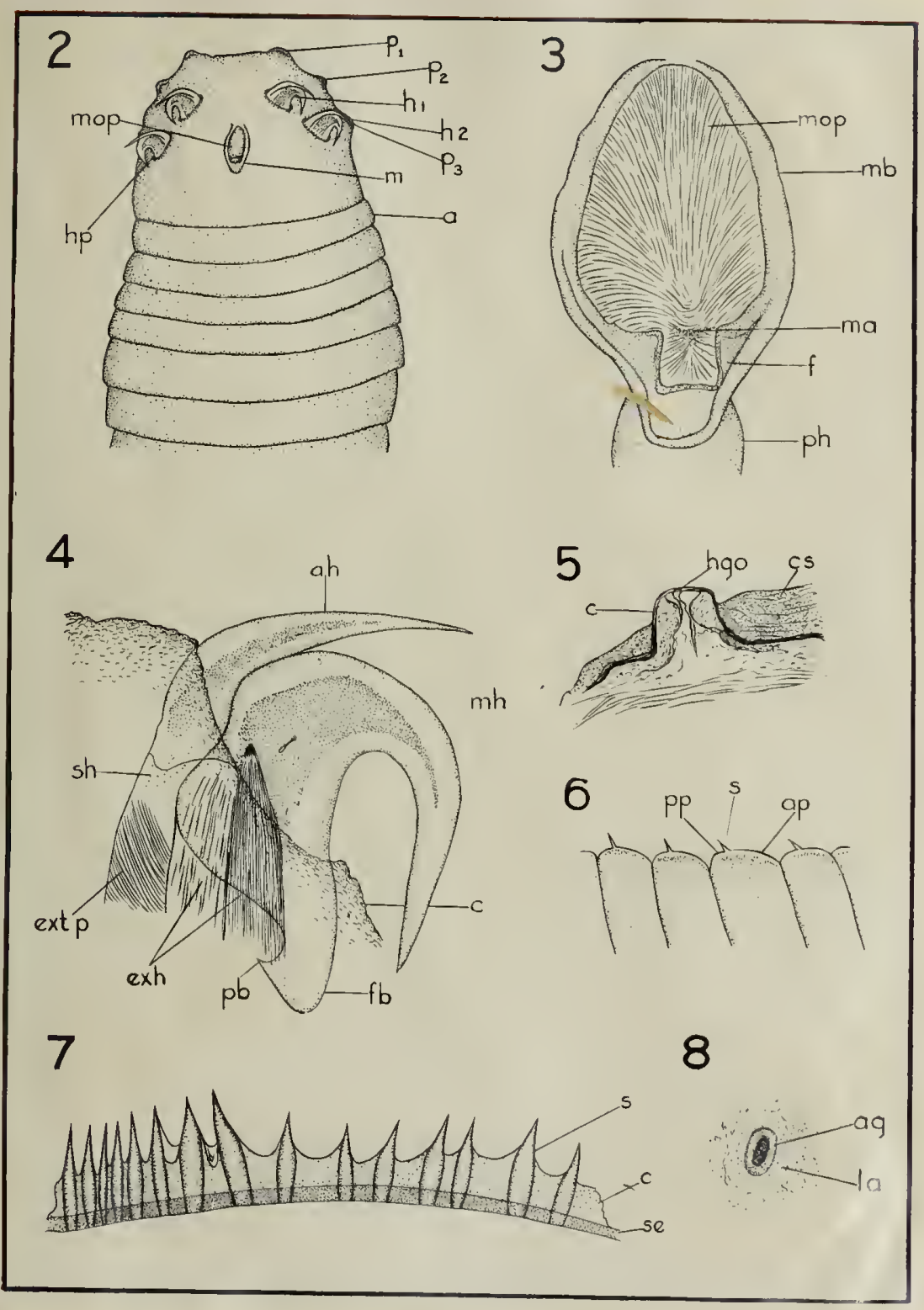





\section{Explanation of Plate \\ Plate III. \\ ibbreviations.}

bc border of cuticle

bh base of hook

bs basal sheath of hook

c cuticle

eh extensor of hook

gl hook gland

h hook

hg head gland

hed head gland duct

hgt hind gut $\mathrm{hm}$ muscles of hook

ho hook pit

Im longitudinal muscles

om oblique muscles

s spines

se sub-cuticular epithelium

st stigmata

$t$ testes

tm transverse muscle

Fig. 9. Cross section of head reqion; x 150 .

Hig. 10. Surface view of cuticle; x 250 .

Fig. 11. Surtace view of muscles of body will; x250.

Fig. 12. Cross section of cuticle; x 400 .

Fig. 13. Cross section of midale of head region; x 150

Fig. 14. Cross section thru region of rind gut; $x 50$. 



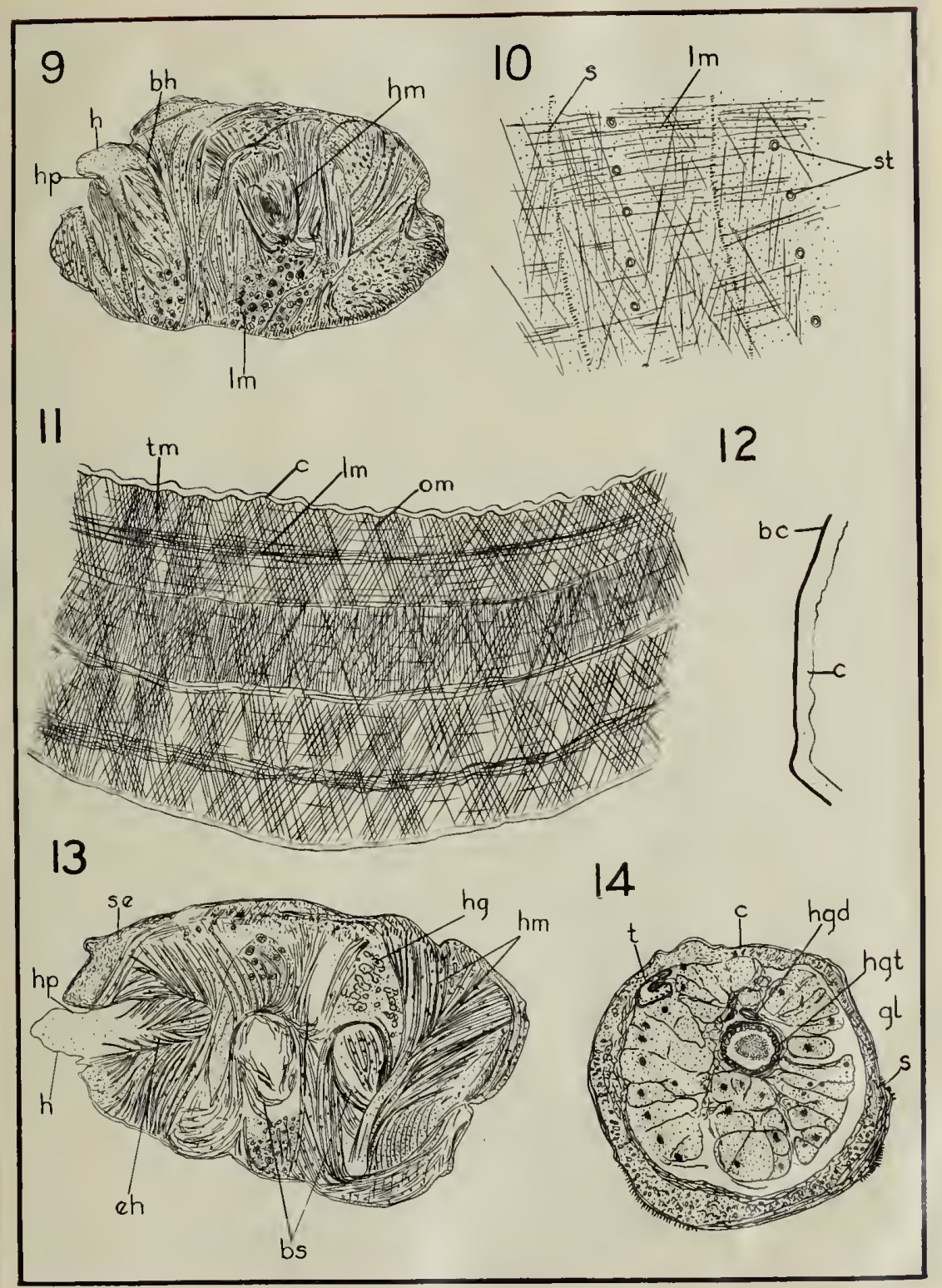



Explanetion of Dlate

Plate IV.

Abbreviations.

\begin{tabular}{|c|c|c|c|}
\hline a & anal opening & hg & hook gland \\
\hline ag & a.trium genitale & hहd & hook gland duct \\
\hline C & cuticle & hgt & hind gut \\
\hline $\mathrm{cb}$ & cirrus bulb & hgw & wall of hook gland \\
\hline e & columnar epithelium & om & oblique muscle \\
\hline $\mathrm{co}$ & coagulum & pe & parietal cells \\
\hline es & cirrus sac & $\mathrm{sp}$ & sperm bundle \\
\hline ct & connective tissue & $\mathrm{r}$ & rügae \\
\hline $\mathrm{cw}$ & wall of cyst & sg & stomach \\
\hline$d s$ & dilator rod sac & $\operatorname{sh}$ & sheath of hook \\
\hline ej & ejaculatory duct & $t$ & testis \\
\hline ep & erternal:protractor of hook & $\operatorname{tm}$ & trinsverse muscle \\
\hline$f$ & cross fibers of mesentery & tv & seminel tube \\
\hline$f 1$ & flexor of hook & $v \hat{\alpha}$ & vas deferens \\
\hline $2 x$ & extensor of hook & VS & vesicula seminalis \\
\hline & & vim & wall of mesentery \\
\hline
\end{tabular}

Fig. 15. Ventro-lateral view of entire specimen showing the position of the hook glands; $x 18$.

Fig. 16. Ventral view of head showing muscular

attachments of hooks; x 160 .

Hig. 17. liale genital orguns from the dorsal side;

$\times 60$.

Fig. 18. Iateral view of anterior male reproductive organs; x 55 .

Fig. 19. Median section thru the hind gut; x 150 .

Fig. 20. Ventral view of encystod larva; y 30 .

Fig. 21. Cross section showirg the layers of the

body weIl: x 400 .

Wig. 2.\%. Cross section in region in region of hind gut showing connections of the mesentery; $\approx 180$. 


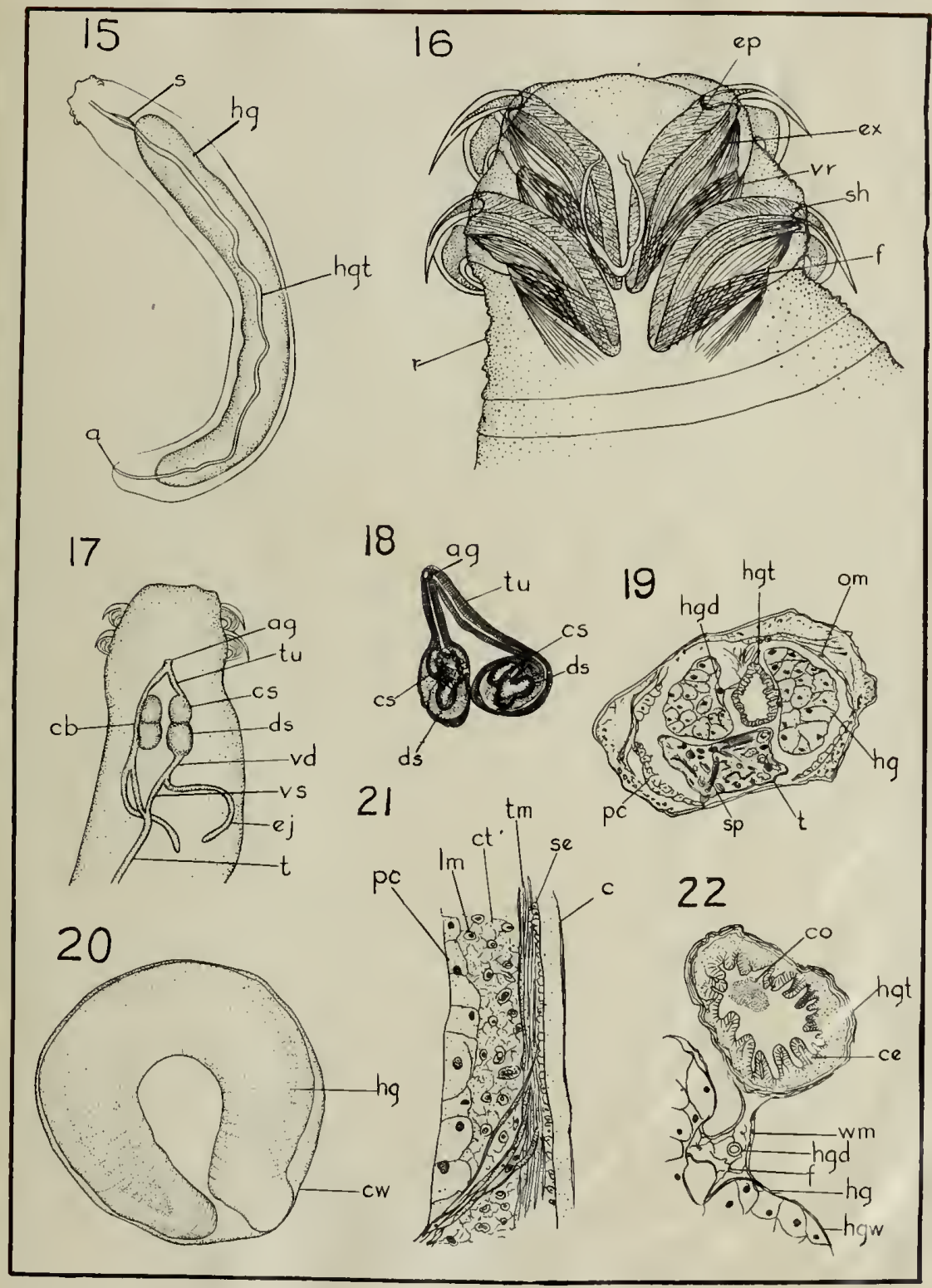





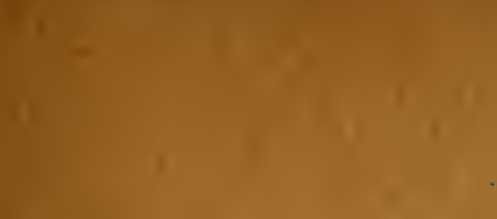

$\cdot$

$1=$

$-$

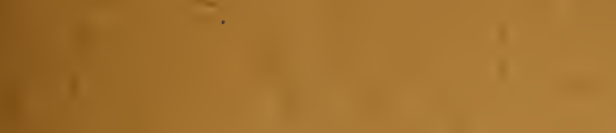

$\pi+1$

1.20

$x^{2}$

$1=$

$y$

1

II

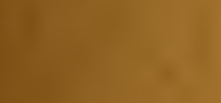

6.

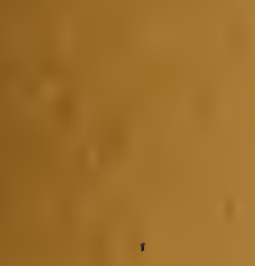

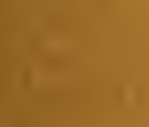

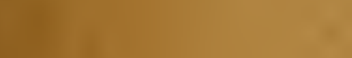

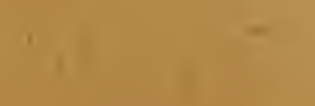$$
-\quad 1 x^{11}
$$

1
.

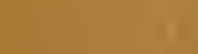

\section{(1) 1}

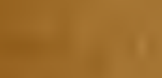

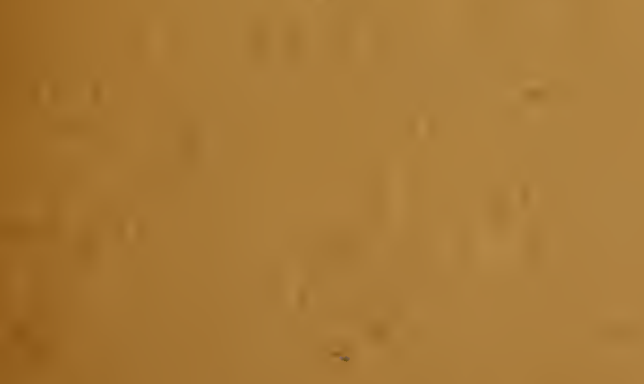

$18+10$ 


\section{UNIVERSTTY OF ILLINOIS-URBANA}

30112086860233 